WSRC-MS- $-91-514$

DE92 009093

\title{
TECHNICAL AND QA PLAN: BOILING BEHAVIOR DURING FLOW INSTABILITY (U)
}

\author{
by \\ D. A. Coutts
}

Westinghouse Savannah River Company

Savannah River Site

Aiken, South Carolina 29808

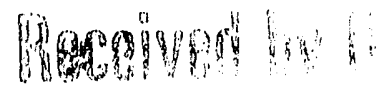

MIAR $1099 \%$

A paper proposed for presentation at the

Review for Dissertation

Columbia, South Carolina

December 1991

\section{DISCLAIMER}

\begin{abstract}
This report was prepared as an account of work sponsored by an agency of the United States Government. Neither the United States Government nor any agency theieof, nor any of their employees, makes any warranty, express or implied, or assumes any legal liability or responsibility for the accuracy, completeness, or usefulness of any information, apparatus, product, or process disclosed, or represents that its use would not infringe privately owned rights. Reference herein to any specific commercial product, process, or service by trade name, trademark, manufacturer, or otherwise does not necessarily constitute or imply its endorsement, recommanufacturer, or otherwise the United States Government or any agency thereof. The views and opinions of authors expressed herein do not necessarily state or reflect those of the United States Government or any agency thereof.
\end{abstract}

This paper was prepared in connection with work done under Contract No. DE-AC09-89SR18035 with the U.S. Department of Energy. By acceptance of this report, the publisher and/or recipient acknowledges the U.S. Government's right to retain a nonexclusive, royalty-free license in and to any copyright covering this report, along with the right to reproduce and to authorize others to reproduce all or part of the copyrighted report. 
OSR 24-K1

Page 1 of 834

\section{Technical and QA Plan}

\section{Title and Approval Page}

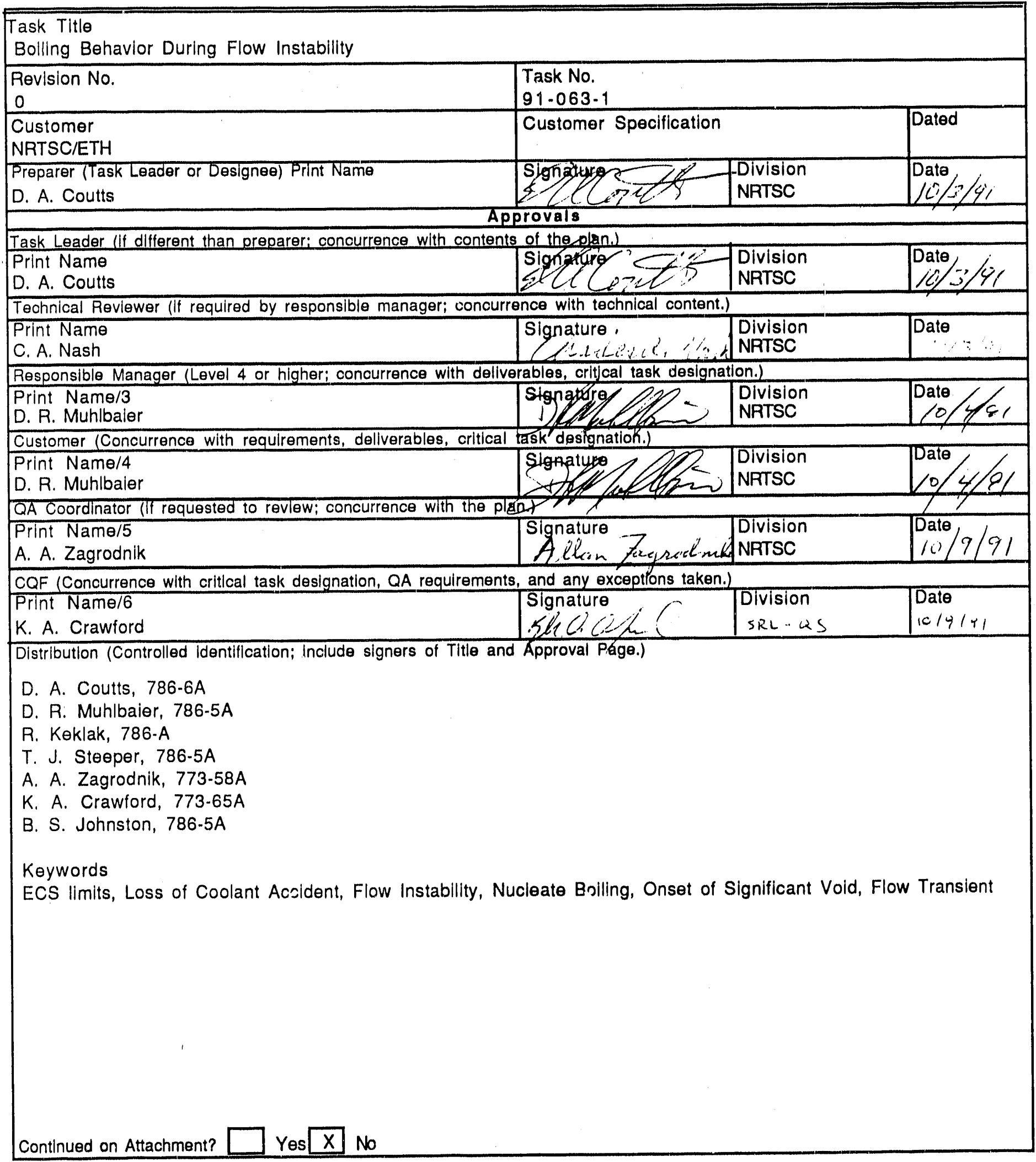


OShA 24-K1

Page 2 of 834

Technical and QA Plan

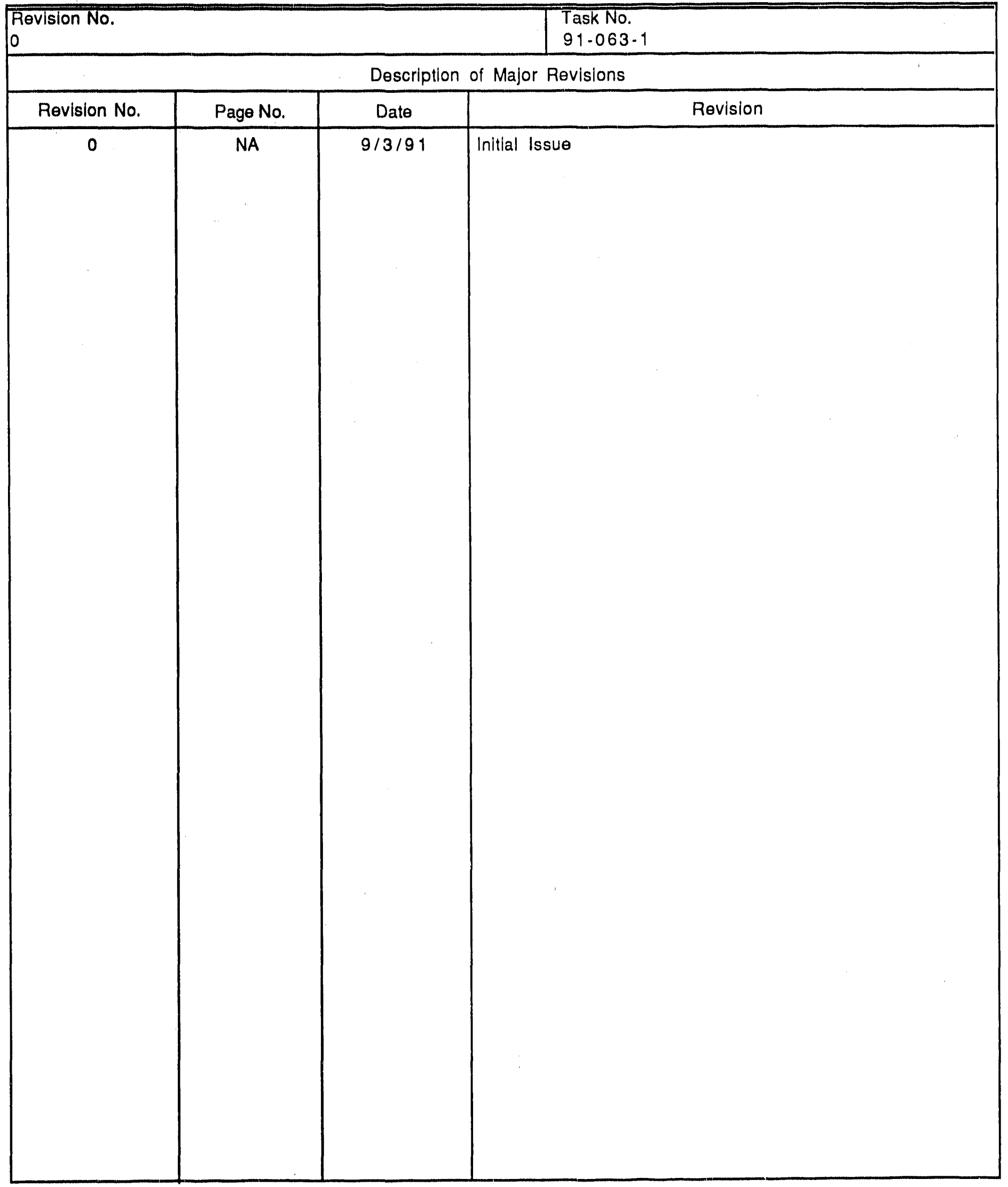

Refer to NRTSC procedure QAP I-2, "Conduct of Technical Activity," for additional Information 


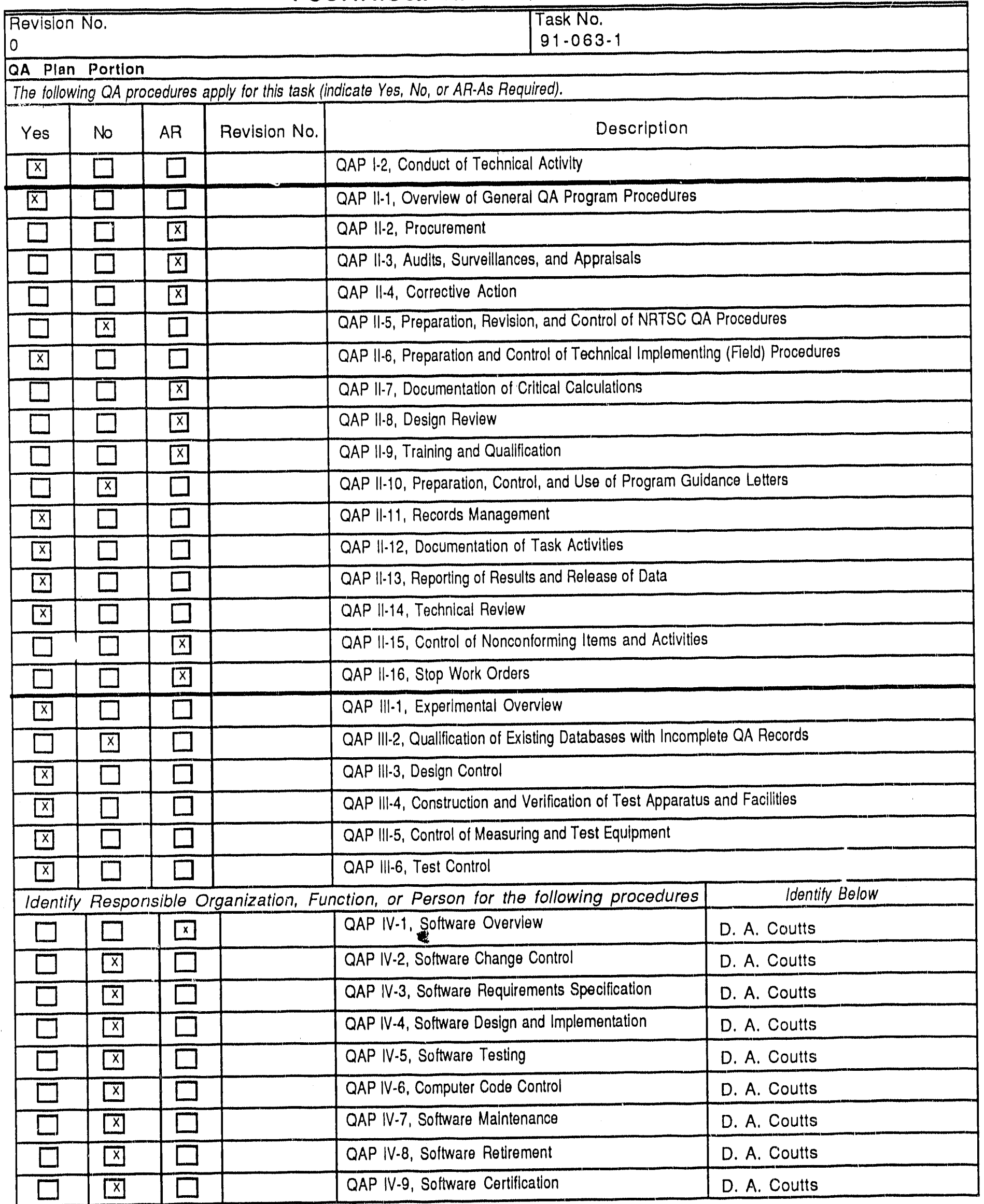

Refer to NRTSC procedure QAP 1-2, "Conduct of Technical Activity," for additional information 


\section{Technical and QA Plan}

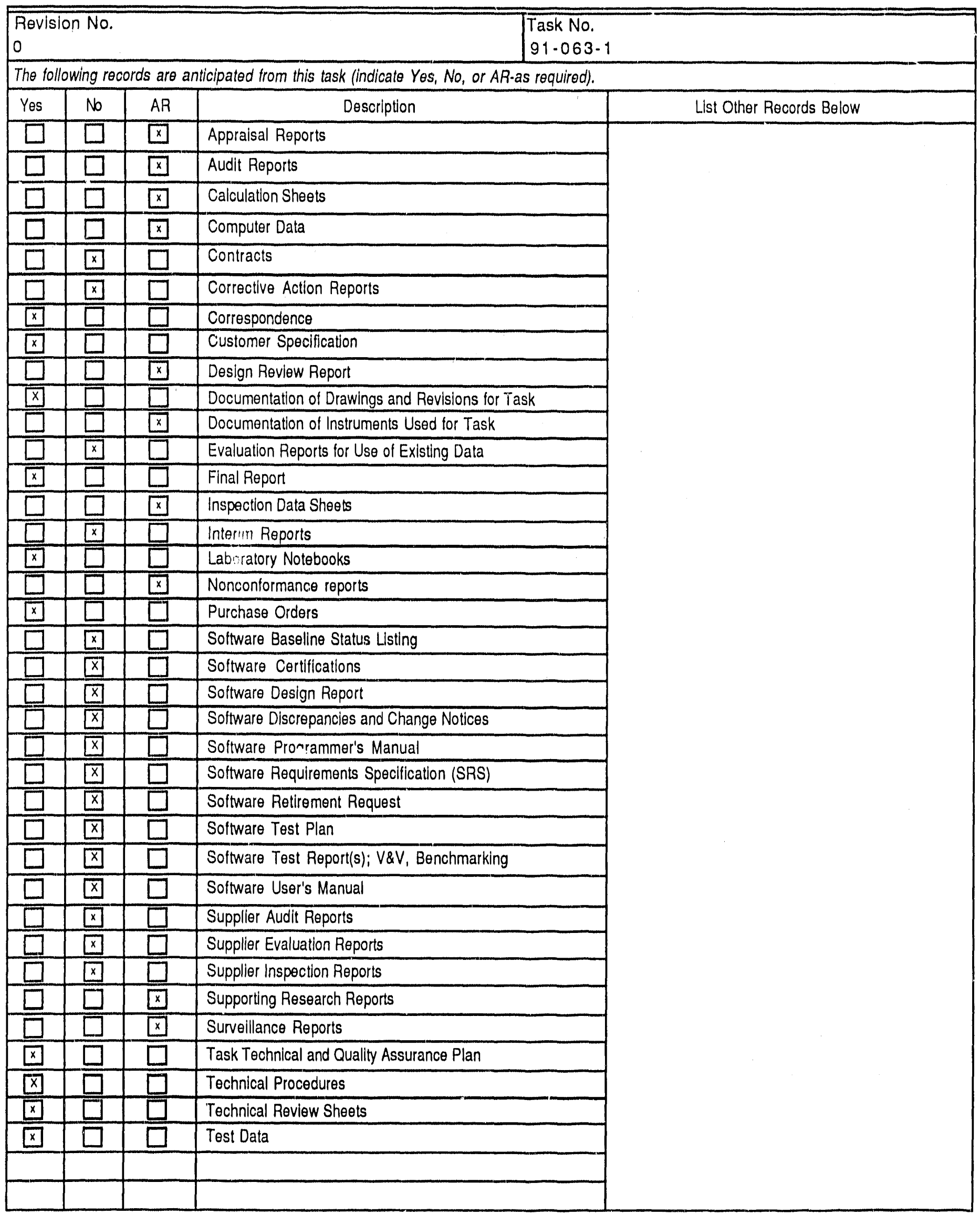




\section{Technical and QA Plan}

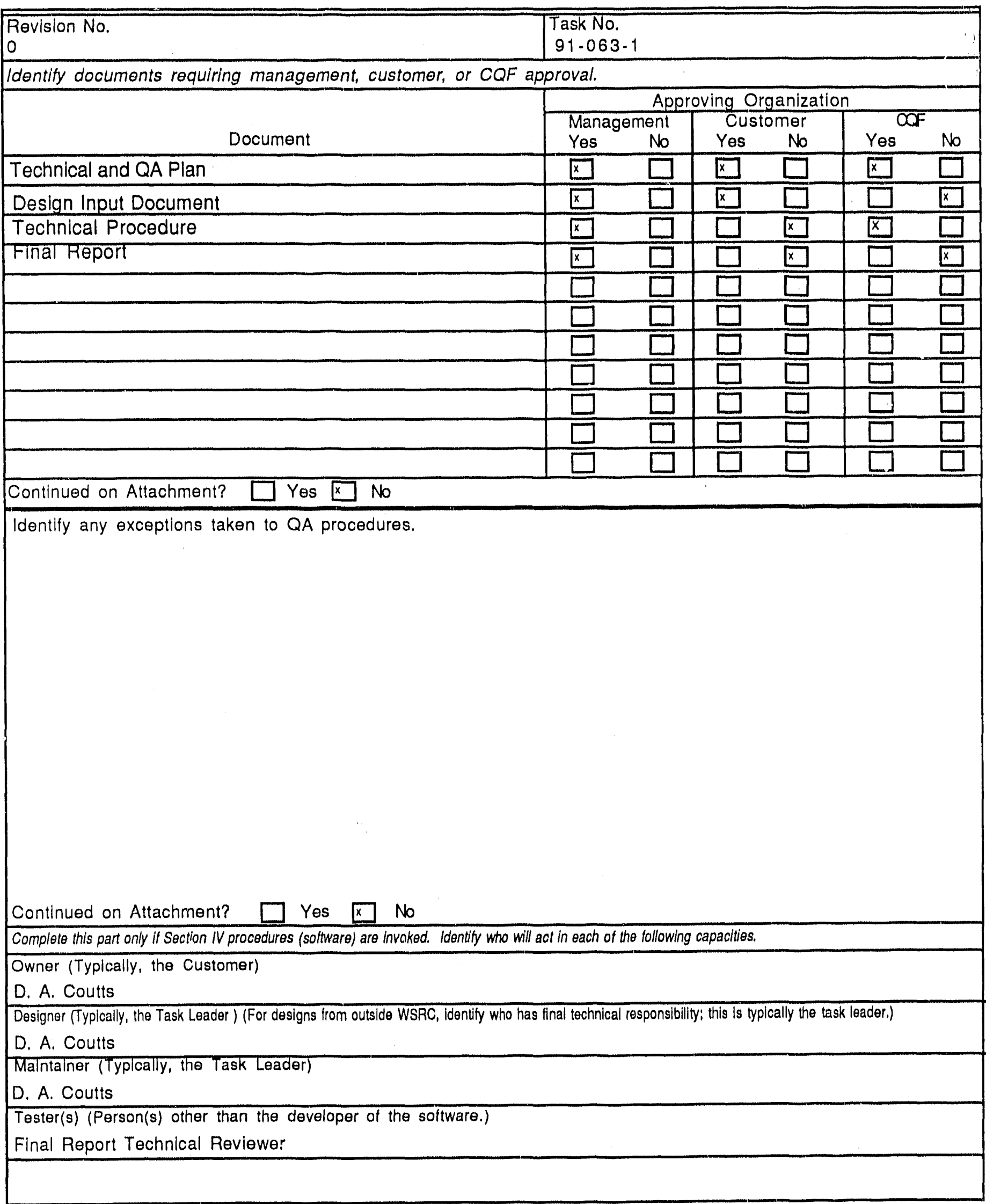




\subsection{APPROVAL PAGE/QA PORTION}

\subsection{INTRODUCTION}

\subsection{Background Information}

The coolant flow in a nuclear reactor core under normal operating conditions is kept as a subcooled liquid. This coolant is evenly distributed throughout the multiple flow channels with a uniform pressure profile across each coolant flow channel. If the coolant flow is reduced, the flow through individual channels will also decrease. A decrease in coolant flow will result in higher coolant temperatures if the heat flux is not reduced. When flow is significantly decreased, localized boilling may occur. This localized boiling can restrict coolant flow and the ability to transfer heat out of the reactor system. The maximum operating power for the reactor may be limited by how the coolant system reacts to a flow instability ${ }^{1}$. One of the methods to assure safe operation during a reducing flow transient, is to operate at a power level below that necessary to initiate a flow excursion. Several correlations have been used to predict the conditions which will preceed a flow excursion? These correlations rely on the steady state behavior of the coolant and are based on steady-state testing.

The individual coolant flow channel behavior during flow excursion is significantly impacted by the multiple path network ${ }^{3}$. When coolant flow is reduced to the flow network the flow through all of flow channels is expected to decrease. If there are no geometric, heat transfer or power dissimilarities the flow to each channel will be equally reduced as a function of the pressure drop across the flow network. In practice the reactor geometry, heat transfer behavior and power flux are not uniform. Some flow channels will be exposed to higher power levels and greater flow restrictions. Because the pressure drop across each channel is the same, as the pressure drop decreases across the entire network some channels will be more susceptible to unstable flow excursions.

When flow through the network is reduced, localized boiling may occur in some of the susceptible channels. This localized boilling may further restrict flow and inhibit heat transfer in the susceptible channels. If the flow reduction is substantial enough, a flow excursion will occur. This process can be seen in Figure 1. Whittle and Forgan generated these demand curves by incrementally reducing the flow through a single channel and measuring the steady state pressure drop at each flow. As the flow was reduced a minimal pressure drop was reached. Further flow decrease resulted in a transition condition and thermal excursion. Four different rectangular geometries and one round tube were evaluated in developing equation 1. Based on these

\footnotetext{
1 Whittle \& Forgan.

2 Whittle \& Forgan, and Saha \& Zuber.

3 Whittle \& Forgan.
} 
evaluations Whittle and Forgan suggested that the onset of the flow excursion can be predicted using equation 1 and that this might coincide with the detachment of water vapor from the channel walls.

$$
R=\frac{1}{1+\frac{\eta}{\left(\frac{L H}{D_{H}}\right)}}=\frac{T_{\text {critical }}-T_{\text {Inlet }}}{T_{\text {sat }}-T_{\text {Inlet }}} \text { where } \eta=25
$$

A second empirical correlation for predicting the conditions which precede flow instability was developed by Saha and Zuber. It is based on the local fluid conditions where the void activity becomes significant.

$$
\begin{gathered}
\mathrm{Nu}=\frac{\phi D_{\theta}}{k_{f} \Delta T_{\lambda}}=455 \text { if } \mathrm{Pe} \leq 70,000 \\
\mathrm{St}=\frac{\phi}{\mathrm{G} \mathrm{c}_{p f} \Delta \mathrm{T}_{\lambda}}=0.0065 \text { if } \mathrm{Pe}>70,000
\end{gathered}
$$

where:

$$
P_{\theta}=\frac{N u}{S t}=\frac{G D_{\theta} C_{p t}}{k_{f}}
$$

Saha and Zuber developed this correlation based on vapor bubble behavior for a variety of fluids (water, Freon-22, Freon-114). The method predicted the Onset of Significant Void (OSV) which has been found to precede a flow excursion. Two criteria must be met to achieve the OSV: (1) The bubbles must detach from the wall. (2) The evaporation rate at the wall (vapor formed at and leaving wall) must he greater than the condensation rate in the liquid core (vapor coridensing in core). Under different flow conditions one of these two criteria will be controlling. It has been found that vapor bubbles detach from the wall at a local roughness number of about 0.02 . This corresponds to a Stanton number of 0.0065 . The condensation and evaporation relationship can be evaluated based on the local Nusselt number. When the Nusselt number exceeds 455 the condensation rate of vapor entering the liquid core will no longer exceed the evaporation rate. This may be restated as: For OSV to occur the Nusselt number must be greater than 455 and the Stanton number must be greater than 0.0065 . The Nusselt number represents the relationship between the evaporation and condensation rates and the Stanton number represents the bubble detachment phenomena criterion. 


\subsection{Purpose of Task}

There are two significant points which this project will try to identify. The first is when vapor first forms on the channel surface. This might be designated as the Nucleate Vapor Transition. (Steady state equivalent is ONB.) The second is when the vapor formation rate is large enough to lead to flow instability and thermal excursion. This point might be designated as the Significant Vapor Transition. (Steady state equivalent is OSV.) A correlation will be developed to relate established steady state relations with the behavior of transient systems.

For all flow conditions (steady state and transient) the nominal wall temperature will exceed the liquid core coolant temperature. At the interface between the wall and the fluid, the temperature will lie between tirese two values. At steady state conditions if the wall temperature is less than the saturation temperature there will be no vapor generation in the channel. For most subcooled conditions, if the flow is marginally reduced there should still be no vapor generation. When the change in flow is great enough, vapor will be generated at the trailing portion of the channel (Figure 2a). For a larger flow transient the point of vapor generation is expected to move upstream (Figure 2b). A still larger flow transient will allow the formation of larger vapor pockets, some of which may break away from the heated surface (Figure 2c). At some magnitude of flow transient, flow will be impeded (Figure 2d). Larger flow transients should result in the formation of large vapor bubbles which significantly impair flow leading to flow instability and a thermal excursion.

\subsection{DESCRIPTION OF TASK}

\subsection{Customer's Requirements}

Bankoff, Lee and Knaani have completed a literature review on ForcedConvection Subcooled Nucleate Boiling. The review documented 4 ONB models, 11 OSV models, 3 bubble boundary layer models and 8 void fraction models. All of the works are based on steady-state forced-convection, subcooled nucleate boiling. No experimental studies were identifled which address transient forced-convection, subcooled nucleate boiling. The next step in their program will be to use the literature review as a basis to develop a theoretical model for transient downflow instability. This task will provide data to be used to benchmark and verify the theoretical model.

\subsection{Test Description}

The test will be performed in the Heat Transfer Laboratory, Building 786-A. The test rig will consist of a vertical flat channel rig which has a heated section about 4 feet long and a nominal flow area of $0.125^{\prime \prime} \times 3^{\prime \prime}$. The transient flows will be produced using a positive displacement pump. In the later stages of 
the testing, transients may be produced using a bypass around the heated channel.

\subsection{Theoretical Basis and Limitations}

Figures 3 and 4 show a variety of thermal hydiaulic correlations 4 . All of these correlations are based on steady state fluid behavior. The information presented in these figures can be used to evaluate what flow instability milestones can be expected to occur during any given flow or power transient.

If the heat flux and mass flux can be presented as parametric relations:

$$
\begin{aligned}
& \phi=\psi_{1}(t) \\
& G=\psi_{2}(t)
\end{aligned}
$$

then the transient trajectory can be imposed on the heat flux, mass flux flow instability milestone plots. At each location where the trajectory inteicepts a flow instability milestone the potential exists for flow instability behavior.

To demonstrate this assume that the heat flux is constant at $1,000,000$ $\mathrm{Btu} / \mathrm{hr}-\mathrm{ft}^{2}$, and the mass flux decreases with time from an initial condition of $2,9000,000 \# / \mathrm{hr}_{-1 t^{2}}$. From Figure 5 it is apparent that none of the flow instability milestone criteria has been exceeded. As the mass flux decreases the first milestone is ONB. The theoretical time to ONB based on steady state behavior can be predicted from this intercept $(G=1,250,000$ $\# / \mathrm{hr}^{\left.-\mathrm{ft}^{2}\right)}$ and equation 6 . As the mass flux drops other milestones occur:

$$
\begin{gathered}
\text { Milestone } \\
\text { Minimum piessure drop } \\
\text { OSV } \\
\text { Quality }=0.0 \\
\text { CHF (soft system) } \\
\text { CHF (hard system) } \\
\text { Quality }=1.0
\end{gathered}
$$

\begin{tabular}{c} 
Mass Flux.G \\
\hline 550,000 \\
500,000 \\
400,000 \\
400,000 \\
50,000 \\
50,000
\end{tabular}

The time to each milestone can then be predicted from Equation 6 . Figure 6 illustrates how the time to a milestone can be calculated for different flow transients.

A similar solution can also be completed for a constant mass flow and an increasing heat flux. For initial conditions: $700,000 \mathrm{Btu} / \mathrm{hr}^{-\mathrm{ft}} \mathrm{2}, 1,250,000$ \#/hr-ft2 (Figure 5) the milestones are: 


$$
\begin{gathered}
\frac{\text { Milestone }}{\text { ONB }} \\
\text { Minimum pressure drop } \\
\text { OSV } \\
\text { Quality }=0.0 \\
\text { CHF (soft system) } \\
\text { CHF (hard system) } \\
\text { Quality }=1.0
\end{gathered}
$$

The theoretical time to each flow instability milestone can be estimated from Equation 5.

A more realistic trajectory might be:

$$
\begin{aligned}
& \phi=\left\{\begin{array}{cc}
10^{6} \frac{\mathrm{Btu}}{\mathrm{hr} t^{2}} & t \leq 0.3 \text { seconds } \\
10^{6}\left(0.9 e^{-4 t}+0.1\right) & t>0.3 \text { seconds }
\end{array}\right. \\
& G(t)=G_{0}\left[0.18 e^{-2.78 t} \sin \left(4.17 t+\frac{\pi}{2}\right)+0.82\right]
\end{aligned}
$$

Where:

$$
G_{0}=2,900,000 \frac{\#}{\mathrm{hr} \mathrm{tt}^{2}}
$$

The parametric solutions are presented in Figure 7; the trajectory is shown in

Figures 8 and 9 . For this trajectory the milestones which are intercepted are:

$$
\begin{aligned}
& \text { ONB } \\
& \text { Minimum pressure drop } \\
& \text { OSV } \\
& \text { Quality }=0.0 \\
& \text { CHF (soft system) }
\end{aligned}
$$

The time to each milestone can be calculated from either equation 5 or 6 using the trajectory intercept data.

Several researchers ${ }^{5}$ have observed a delay between the predicted time to the onset of flow instability (as defined by DNB or CHF) using steady state models and the experimentally observed time to flow instabillty. In some cases the predicted time was less than $20 \%$ of the observed time $e^{6}$. The data was correlated in a variety of ways. Most correlated the actual heat or mass

5 Moxon and Edwards; Celata, D'Annibale, Farello, Setaro and Cumo; Cumo, Fabrize and Palazzi; and Lahey et al. 
flux at instabillty with the predlcted heat or mass flux at instability as a function of physical parameters and transient quickness.

\subsection{Range of Test Conditions}

\subsubsection{Identiflcation of Variables}

The data, theoretical relations, and correlations on two-phase flow exhibit wide ranges of uncertainty; in many cases standard deviations of 25 to $50 \%$ are considered acceptable. This wide variation makes it imperative that the rig be characterized. This process will entail characterizing the apparatus for the following conditions.

1. Subcooled, isothermal, steady-state water flow,

2. Saturated, isothermal, steady-state steam flow,

3. Saturated, isothermal, transient water flow,

4. Steady-state, water flow S-curves (heated)

Significant parameters for transient boiling behavior which should be evaluated can be predicted based on the previously discussed steady state correlations.

Variables from Equation 1 include, the coolant temperature supplied to the flow channel, the heated length and the heated hydraulic diameter. The two variables which are expected to be most readily adjusted are the coolant temperature and the hydraullc diameter (channel thickness).

Variables from Equations 2, 3, and 4 include, the heat flux, the hydraullic diameter, and the mass flow rate. This introduces two additional variables which ran be readily varied: The heat flux and the coolant flow.

Another significant variable which should be evaluated is the flow direction. The behavior of the transient response could be significantly impacted by a charge from down-flow to an up-flow configuration. Since the two-phase flow regimes for downward and upward flow are very different 7 , it is possible that the flow direction impacts the transient response behavior.

The application of transients introduces an additional variable which should be evaluated. The most significant is the rate of the flow transient. It is expected that very slow transients will exhibit a strong similarity to steady state data. More rapid transients could result in a situation where it is possible to pass through a normally unstable state and achleve an alternative steady state condition. Possible variations of transient conditions could include a step change and a ramp function (Figure 10). 
The variables to be evaluated during this task are listed in Table 1. The heated length will remain constant for the task; the remaining variables will be evaluated.

\subsubsection{Evaluation of Variables}

It is unknown which variables will have a significant impact on transient flow phenomena. For this reason it is not possible to describe all of the task test conditions. As a minimum each test variable will be evaluated at two test conditions to determine if a relationship exists. The preliminary principle norilina! operation conditions are listed in Table 2. The primary conditions will be evaluated for flow transient changes (measured as the ratio of final mass flux and initial mass flux) of 0.05 to 1.0 . The primary conditions will serve as a baseline of comparison for the effect of the secondary condition evaluation. Each secondary condition will be evaluated individually. Those test conditions fourid to have a significant effect may be evaluated at additional test conditions.

\subsubsection{Test Condition Discussion}

Channel depth - The flow passage depth has been selected to minimize the necessary flow rate but still provide adequate area to allow observation of vapor bubbles leaving the heated surface. The channel depth also is similar to the channel depth used by Whittle and Forgan. The secondary depth approaches that used in SRS reactor assemblies.

Channel exit pressure - The SRS reactors operate at atmospheric conditions. The selected pressure allows a nominal pressure gradient from the exit of the test section.

Channel length - An extremely long flow channel would make it difficult to inspect the channel at all flow points. A short flow channel would require extremely high power densities. A heated length of 4 feet is expected to be manageable. The unheated inlet will be two feet (100 hydraulic diameters) and the exit will be one foot (50 hydraulic diameters). The exit was kept shorter because of the significant two-phase pressure drop in this section. The overall length of the test channel with end connections will be about nine feet.

Channel width - The channel width should be kept as narrow as possible to reduce flow and allow better edge visualization. The channel width must be wide enough to reduce edge effects and allow visualization from the front. The edge effects are thought to be significant if the channel depth is larger than 10 percent of the channel width (proposed design: $0.125 / 3=4 \%$ ). Small channel widths may not allow for adequate visualization (See Figure 9.) For initial design efforts a channel width of three inches has been selected. This 
width will be iterated during the design effort based on scoping evaluations and design detail information. It is desirable to minimize the width.

Flow direction - The present SRS reactors operate in an downflow mode. It is desirable to obtain data based on this arrangement. The proposed New Production Reactor and selected components in the existing reactor (septifoil cooling) operate with Lipflow. Data should be obtained to support efforts related to these second tw'o conditions.

Heat flux - The heat flux will be selected based on the amount of water flow. The water flow is a function of the Reynolds number. The initial water flow prior to the transient will be $120 \%$ of the flow estimated by equation 1 at the critical temperature.

Imposed flow transient - The primary transient flow curve will be a step function. This shape was chosen since it is expected to create the largest effect. The transient will be induced by varying the pump speed. Data will be evaluated based on the actual flow transient. The second test condition will be selected based on the transient flow characteristics of the test rig. Other flow transients such as a ramp change may also be evaluated.

Inlet temperature - For this task the inlet flow will always be subcooled. The $60^{\circ} \mathrm{C}$ temperature is considered easy to achifve and representative of the conditions at SRS. It also provides a good variation for the secondary condition.

Reynolds number - The Reynolds number will be based on the initial conditions prior to the transient. The values selected include both laminar and turbulent flow. It is expected that the pressure drop during two-phase flow will be significant, and it will be necessary to characterize the curve for at least one heat flux in the upper higher quality flow region $(\sim 30 \%)$. If the rig design pressure is limited to $45 \mathrm{psig}$ and the operation range to $30 \mathrm{psig}$, the flow witr. $R e=60,000$ will probably exreed the rig design pressure before reaching $3 \%$ quality. (The uncertainty on the calculation is very high.) For $R e=10,000$ it should be possible to achieve high quality flow without exceeding the rig design pressure. The selected flow rates will be adjusted to provide good variable separation and allow operation within the rig design limits.

\subsection{Sources of Input Data}

None

\subsection{Tasks and Estimated Schedule}

3.6.1 Write Task Experimental Plan -D. A. Coutts - 8/31/91

3.6.2 Obtain approvals for Task Plan - D. A. Coutts - 8/31/91 
3.6.3 Write operating procedure - D. A. Coutts - 10/31/91

3.6.4 Design test rig - T. J. Steeper - 10/20/91

3.6.5 Fabricate test rig - T. J. Steeper - 11/30/91

3.6.6 Finish testing - D. A. Coutts - 4/30/92

3.6.7 Document results - D. A. Coutts -12/31/92

\subsection{Purchases}

The operation of this rig will require some specialized instruments to measure flow profile effects near the heated plate. This equipment may not be available before $12 / 91$ therefore some testing will be done prior to receiving this equipment.

\section{$3.8 \quad$ Training}

D. A. Coutts or his designate will train the technicians in specialized activities associated with this task.

\subsection{TEST APPARATUS}

4.1 Test Apparatus Description - The test apparatus is shown in Figure 11. The test channel will have a flow area which is nominally 0.125 " $\times 3^{\prime \prime}$. The heated surface will be $4^{\prime}$ long and $3^{\prime \prime}$ wide. Heating of this surface will be accomplished by electric resistance effects. The heated surface will be visible since vision panels will be provided as shown in Figures 12 and 13. A positive displacement pump will be used to allow steady-state operation on the negative slope portion of the S-curve. The discharge from the pump will be damped and moderately throttled. The throttling should reduce density wave effects. The discharge from the heated channel will be cooled in a heat exchanger supplied from the Building 786-A water system.

\subsection{Instrumentation}

4.2.1 Pressure Gages, 2, 0 to 60 psig, Category 1

4.2.2 Pressure Gages, 4,0 to 60 psig, Category 1

4.2.3 Pressure Gageis, 4,0 to 10 psid, Category 1

4.2.4 Pressure Gages, 2,0 to 5 psid, Category 1

4.2.5 Water Flowmeter (electric), 1,0 to $11 \mathrm{gpm}$, Category 1

4.2.6 Water Flowmeter (rotometer), 1, 0 to $11 \mathrm{gpm}$, Category 1

4.2.7 Water Flowmeter (electric), 1,0 to $3 \mathrm{gpm}$, Category 1

4.2.8 Water Flowmeter (rotometer), 1,0 to $2.7 \mathrm{gpm}$, Category 1

4.2.9 Thermocouples, Standard Type E, 22,0 to $300^{\circ} \mathrm{C}$, Category 1 
4.2.10 Thermocouples, Test Response Type E, 6, 0 to $300^{\circ} \mathrm{C}$, Category 1

4.2.11 Thermomever, 1,0 to $120^{\circ} \mathrm{C}$, Category 1

\subsection{INVESTIGATION AND TEST PROGRAM}

The test rig will be characterized for a variety of steady-state and transient flow conditions. Pressure drop che.racterizations will be developed for:

- Steady-state, isothermal, subcooled water, 20 and $60^{\circ} \mathrm{C}, 0$ to $11 \mathrm{gpm}$

- Steady-state, isothermal, saturated steam, maximum flow will be based on test apparatus design pressure

- Transient isothermal, subcooled water, 20 and $60^{\circ} \mathrm{C}, \mathrm{Re}$, step and range conditions stated in Section 3.4.3

- Steady-state, S-curves as stated in Section 3.4 .3 (2 or 3 power levels)

- Two phase transient tests as stated in Section 3.4.3 (2 or 3 power levels)

\subsection{DATA ACQUISITION, REDUCTION AND EVALUATION OF DATA}

6.1 Data Acquisition - Data will be recorded using Workbench software on Macintosh computers.

6.2 Data Reduction - Transient pressure and temperature data will be plotted with respect to time. Pressure data will also be normalized using isothermal data. Tabular and graphical data will be recorded.

6.3 Data Evaluation - Steady state data will be evaluated by comparison with known established relations. Single phase data will be evaluated using:

$$
f \equiv \frac{\Delta p}{4(L / D))\left(\rho V^{2} / 2\right)}
$$

where:

$$
\begin{array}{lll}
f=16 / R \theta & \text { laminar } \\
f=\frac{0.0791}{R e^{0.25}} & 3 \times 10^{3}<R e<2 \times 10^{4} & \text { turbulent } \\
f=\frac{0.046}{R e^{0.20}} & 2 \times 10^{4}<R e<5 \times 10^{5} & \text { turbulent }
\end{array}
$$

Two-phase steady state data will be evaluated using Friedel's (1979) correlation. (See Figure 15.) 
Single-phase transient effects will be evaluated using a variety of curve fits proposed in the avallable literature.

Two-phase data will be evaluated by developing a comparison with singlephase data.

\subsection{REFERENCES}

Bankoff, S. G., S. C. Lee and A. Knaani, Literature Review on Forced-Convection Subcooled Boiling (U), WSRC-TR-91-98, Westinghouse Savannah River Company, February 1991.

Letter to Protessor Larry Hawkins, USC, from D. A. Coutts, "Dissertation Proposal", December 16, 1990.

Coutts, D. Allan, Literature Investigation for Boiling Behavior During Flow Instability, Draft, April 9, 1991.

Letter to S. George Bankoff, from D. A. Coutts, Boiling Behavior During Flow Instability, NES-ETH-910252, April 25, 1991

Hewitt, G. F. "Flow Regimes", Hetsroni, Gad, Handbook of Multiphase Systems, Hemisphere Publishing Corporation, Washington, page 2-3 through 2-40, 1982.

Rohsenow, Warren M., and Harry Choi, Heat, Mass and Momentum Transfer, PrenticeHall inc., Englewood Cliffs, NJ, 1961.

Saha, P. and N. Zuber, "Point of Net Vapor Generation and Vapor Void Fraction in Subcooled Boiling", International Heat Transfer Conference, 5th Proceedings, Tokyo, Japan, September 3-7, 1974, pages 175 - 179.

Whittle, R. H. and R. Forgan, "A Correlation for the Minima in the Pressure Drop Versus Flow-Rate Curves for Sub-Cooled Water Flowing in Narrow Channels", Nuclear Engineering and Design 6, North-holland Publishing Company, Amsterdam, 1967, pg 89-99.

Collier, John G., Conective Boiling and Condensation, 2nd ed., McGraw-Hill, New York, 1972.

Celata, G. P., F. D'Annibale, G. E. Farello, T. Setaro, and M. Curno, "Flow Transients Experiments with Refrigerant-12", Comitato Nazionale per la Ricerca e per 10 Sviluppo Dell'energia Nucleare e Delle Energie Alternative, ISSN/0393-6325, 1986. 
Curno, M., F. Fabrizi, and G. Palazzi, "Translent Critical Heat Flux in Loss-of-FlowAccidents (LOFA)", Internaltion Journal of Multiphase Flow, Voume 4, pp 497$509,1978$.

Katto, Y., "General Features of CHF of Forced Convection Boiling in Uniformly Heated Fectangular Channels", Internaltional Journal of Heat and Mass Transfer, Volume 24, Number 8, pp 1413-1419, 1981.

Lahey Jr., R. T. , B. S. Shiralkar, J. M. Gonzalez and L. E. Schnebley, The Arialysis of Transient Critical Heat Flux, GEAP-13249, General Electric, April 1972.

Mishima, K. and H. Nishihara, "The Effect of Flow Direction and Magnitude on CHF for Low Pressure Water in Thin Rectangular Channels", Nuclear Engineering and Design, Volume 86, North-Holland, Amsterdam, 1985, pp 165-181.

Moxon, D., and P. A. Edwards, Dryout During Flow and Power Transients, AEEW-R553, Atomic Energy Establishment, Winfrith, England, October 1967.

\subsection{NOMENCLATURE}

\subsection{General}

$\begin{array}{ll}A & \text { Flow area of the heated channel } \\ a & \text { Heated channel width } \\ b & \text { Heated channel depth } \\ C_{p f} & \text { Specific heat at constant pressure for the fluid } \\ D_{\theta} & \text { Hydraullc diameter of the heated channel, } \frac{4 A}{P} \\ D_{H} & \text { Heated hydraulic diameter of the channel, } \frac{4 A}{a} \\ f & \text { Friction factor as defined in section } 6.3 \\ G & \text { Mass flux rate } \\ g & \text { acceleration due to gravity } \\ k_{f} & \text { Thermal conductivity of the fluid } \\ L & \text { Channel length } \\ L_{H} & \text { Heated length of the channel } \\ P & \text { Wetted perimeter of the heated channel } \\ \Delta p & \text { Pressure drop } \\ R & \text { Temperature ratio as defined in equation } 1 \\ R e & \text { Reynolds number } \\ t_{0} & \text { Time that the flow transient starts } \\ t_{1} & \text { Time when steady state is achieve after a flow transient } \\ \Delta T_{\lambda} & \text { (Tsat }- \text { Tlocal) at the excursion } \\ T_{\text {sat }} & \text { Saturation temperature of the fluid } \\ V & \text { Mean velocity } \\ \phi & \text { Heat flux into the channel } \\ \mathrm{P} & \text { density }\end{array}$




\subsection{Subscripts:}

$\begin{array}{ll}f & \text { Return to a steady state condition after a transient } \\ \text { ONB } & \text { Start of a transient } \\ \text { Onset of Nucleate Boiling } \\ \text { OSV } & \text { Onset of Significant Void } \\ L & \text { Liquid property } \\ G & \text { Vapor (gas) }\end{array}$




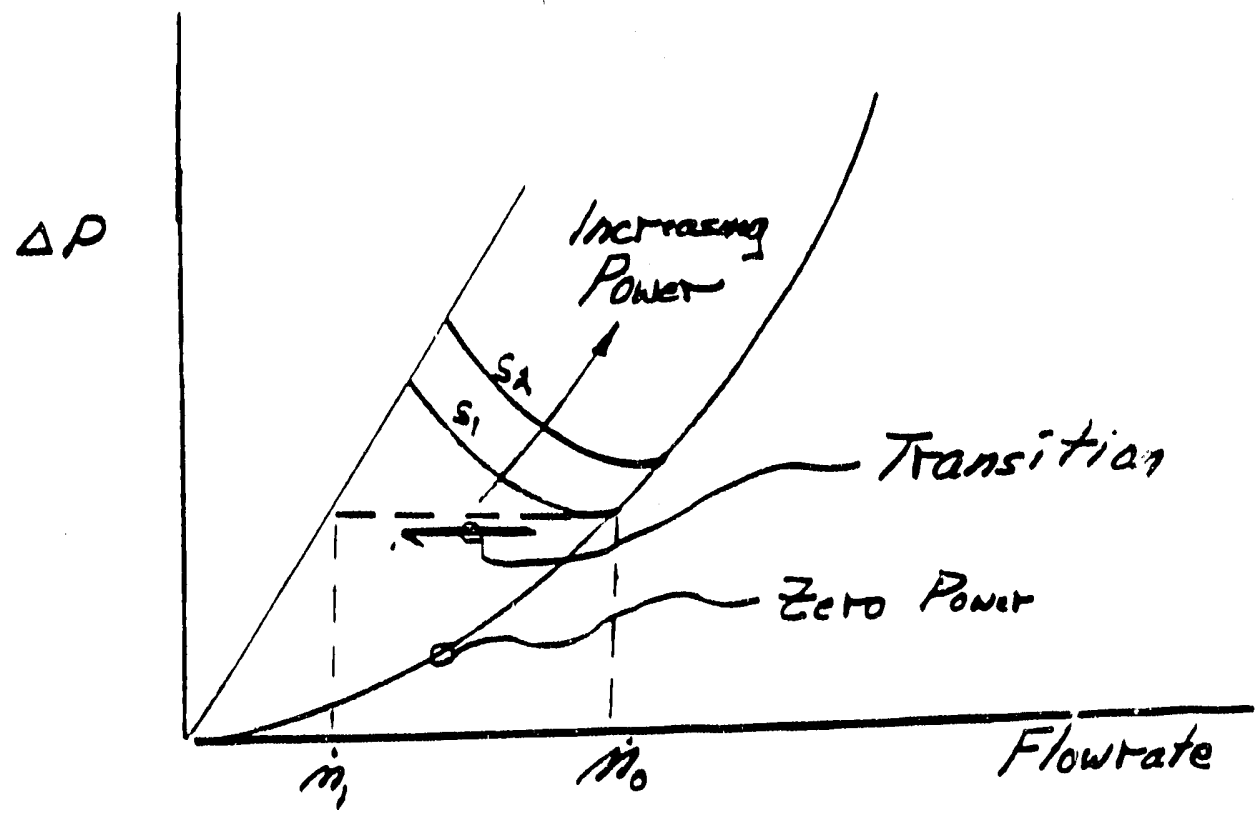

Figure 1, S Curve 

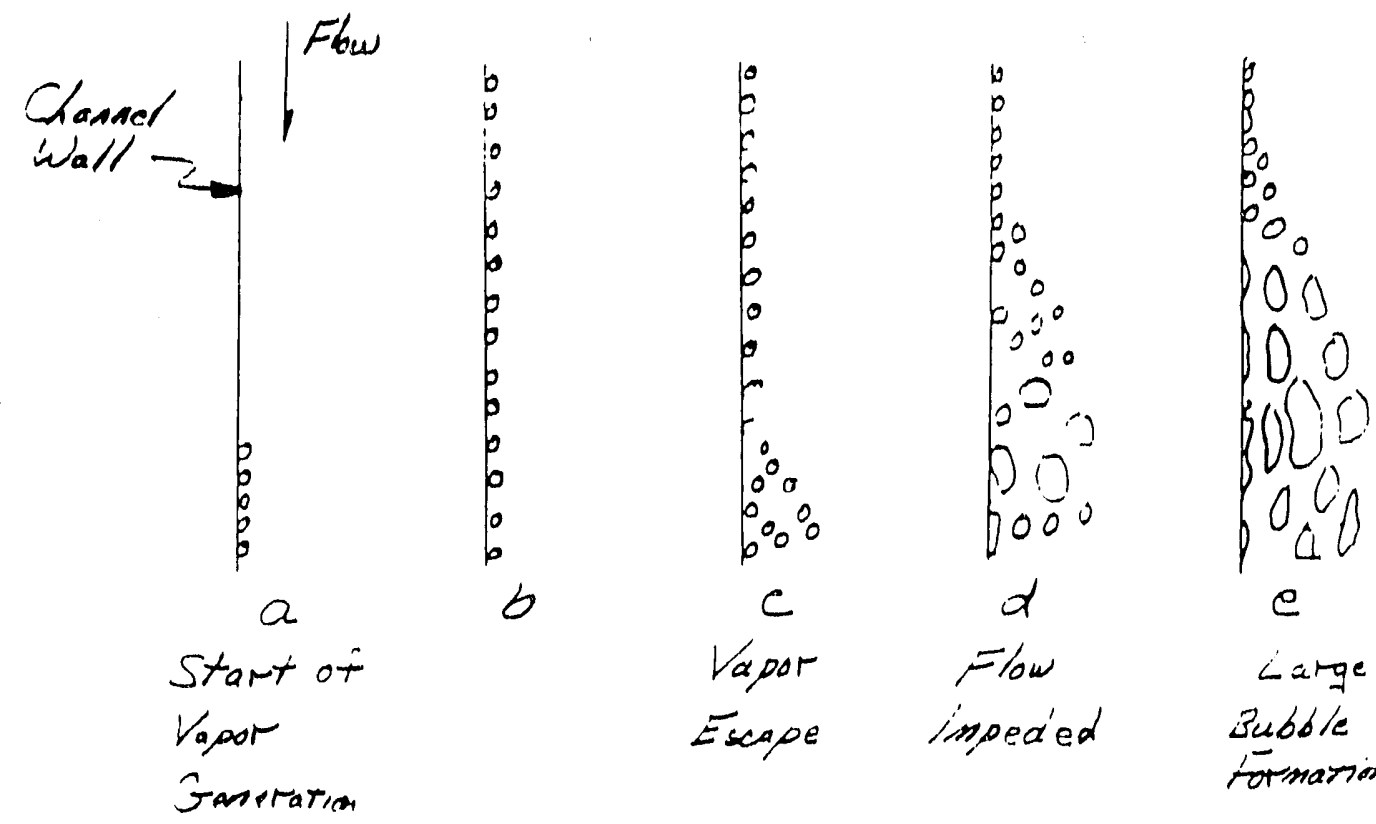

e Large

Bubble

formarion

Figure 2, Vapor Generation Patterns 


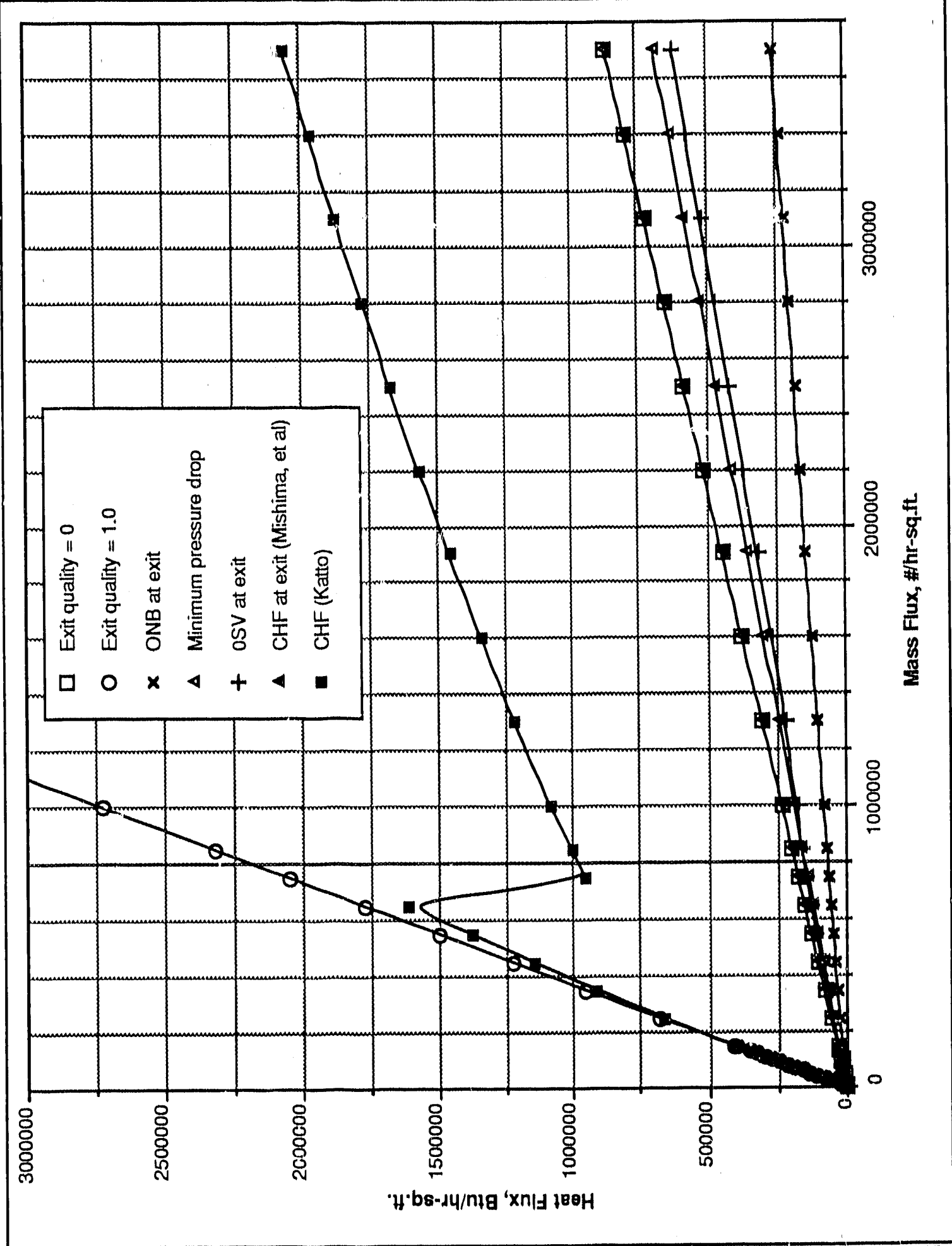

Figure 3, Flow Instability Milestones (Inlet Temperature of $140^{\circ} \mathrm{F}$, high flows) 
TASK EXPERIMENTAL PLAN BOILING BEHAVIOR DURING FLOW INSTABILITY Category 1
Number: 91-063-1

Revision: 0

$9 / 6 / 91$

Page 22 of 34

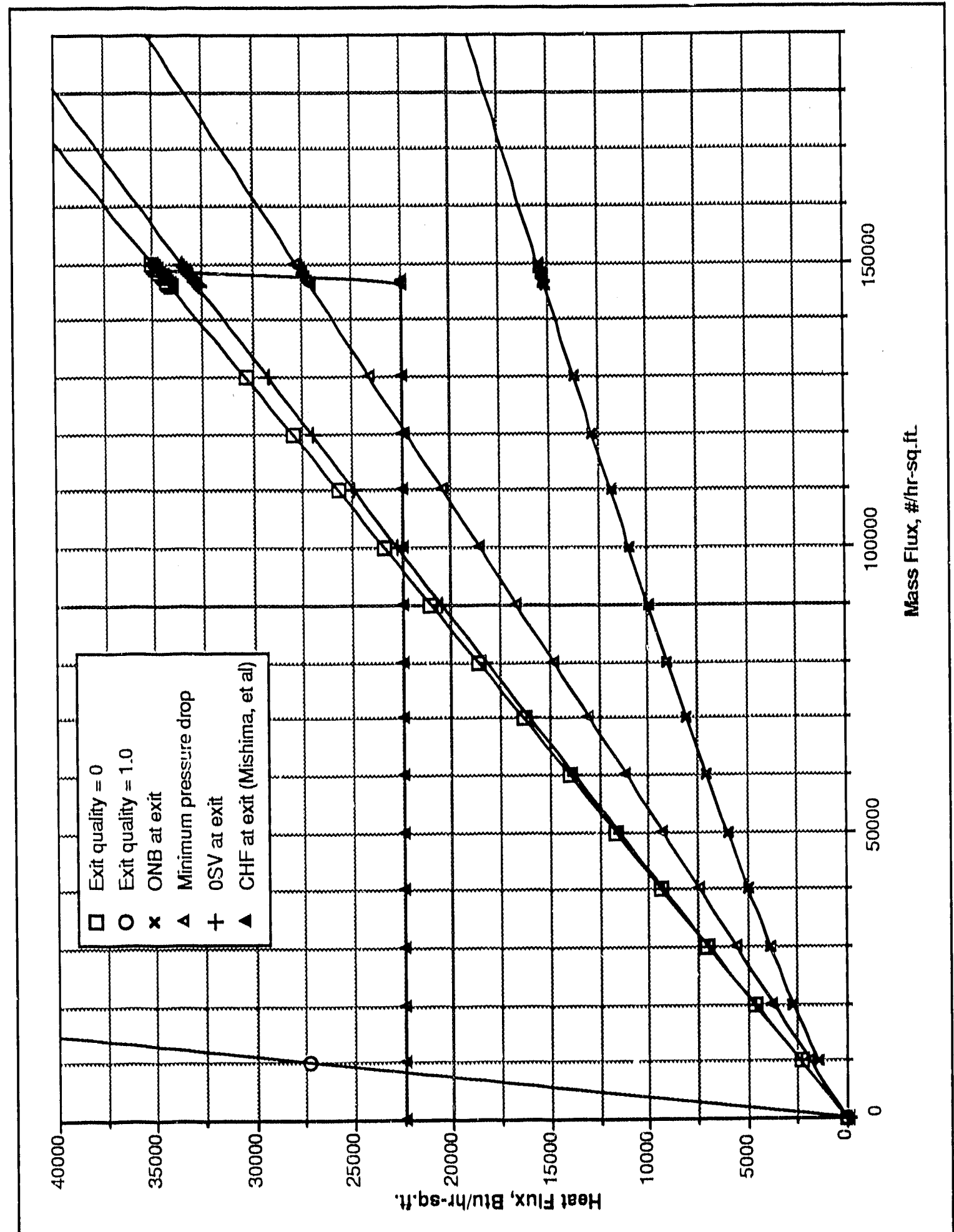

Flgure 4, Flow Instability Milestones (Inlet Temperature of $140^{\circ} \mathrm{F}$, low flows) 


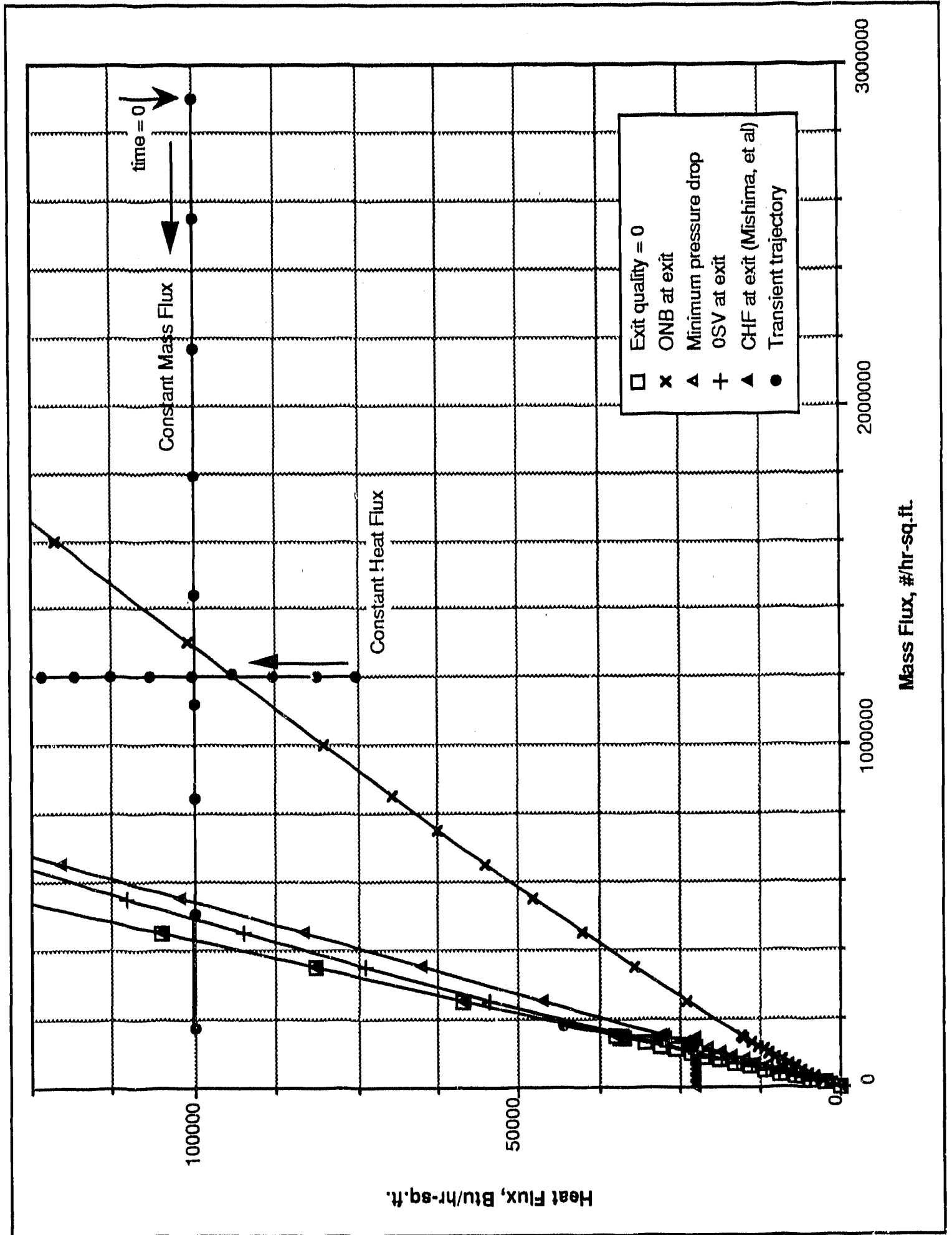

Figure 5, flow Transient Trajectories 
TASK EXPEFIIMENTAL PLAN

BOILING BEHAVIOR DURING FLOW INSTABILITY Category 1
Number: $\quad 91-063-1$

Revision: 0

9/6/91

Page 24 of 34

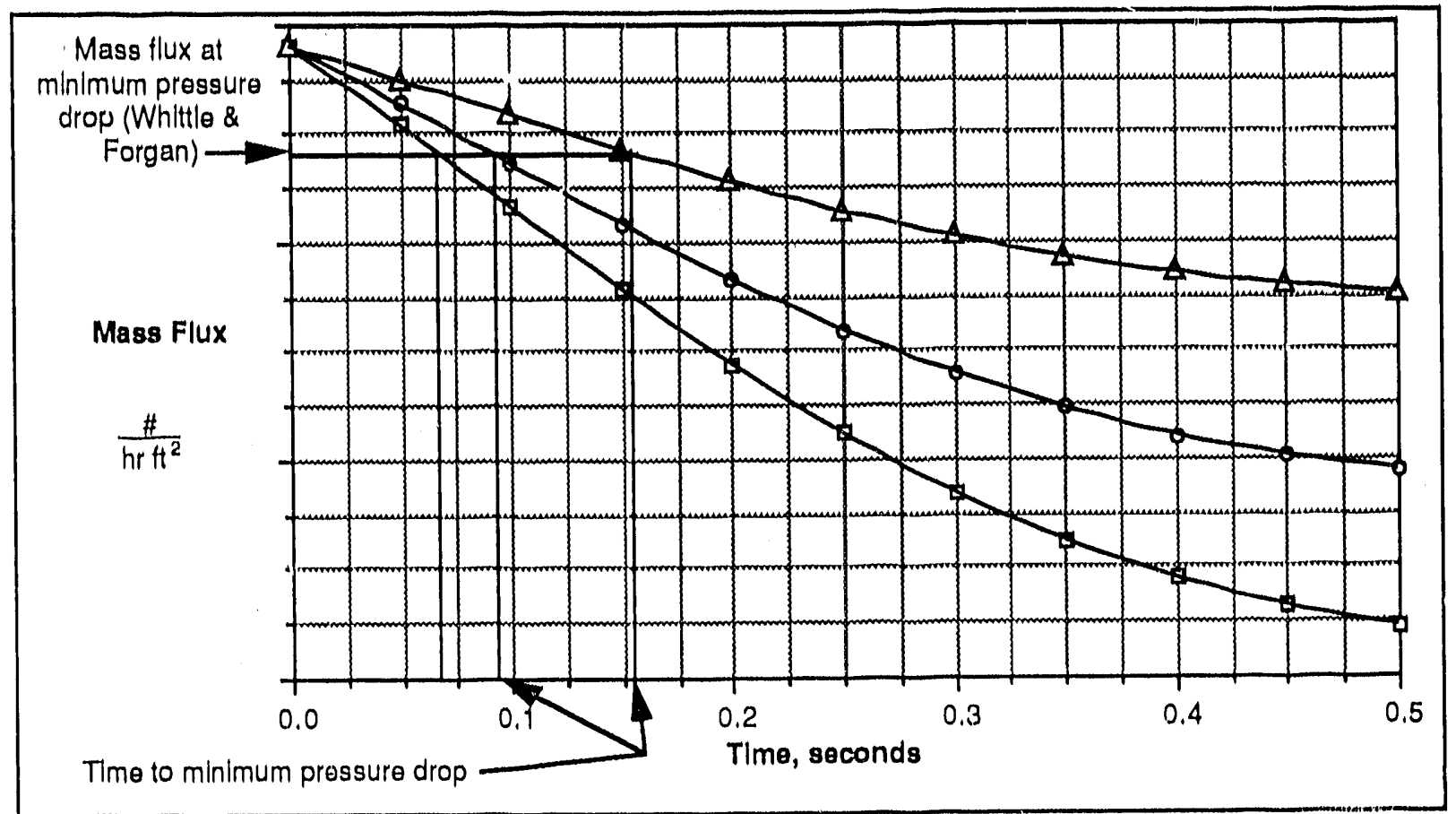

Figure 6, Time to Minimum Pressure Drop 
TASK EXPERIMENTAL PLAN

BOILING BEHAVIOR DURING FLOW INSTABILITY

Category 1
Number: 91-063-1

Revision: 0

$9 / 6 / 91$

Page 25 of 34

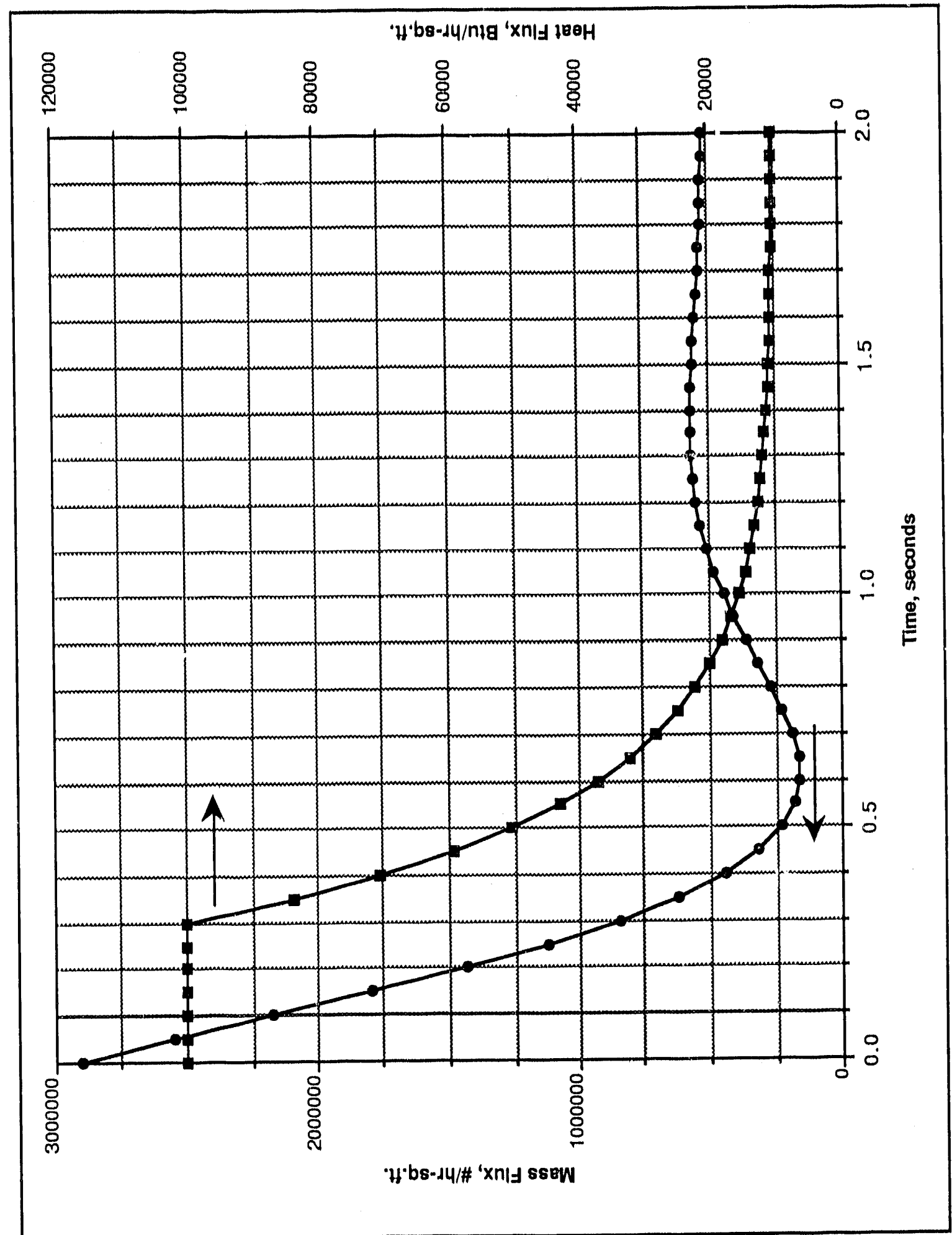

Figure 7, Example Parametric Mass Flux and Heat Flux Relations 
TASK EXPERIMENTAL PLAN

BOILING BEHAVIOR DURING FLOW INSTABILITY Category 1
Number: $91-063-1$

Revision: 0

9/6/91

Page 26 of 34

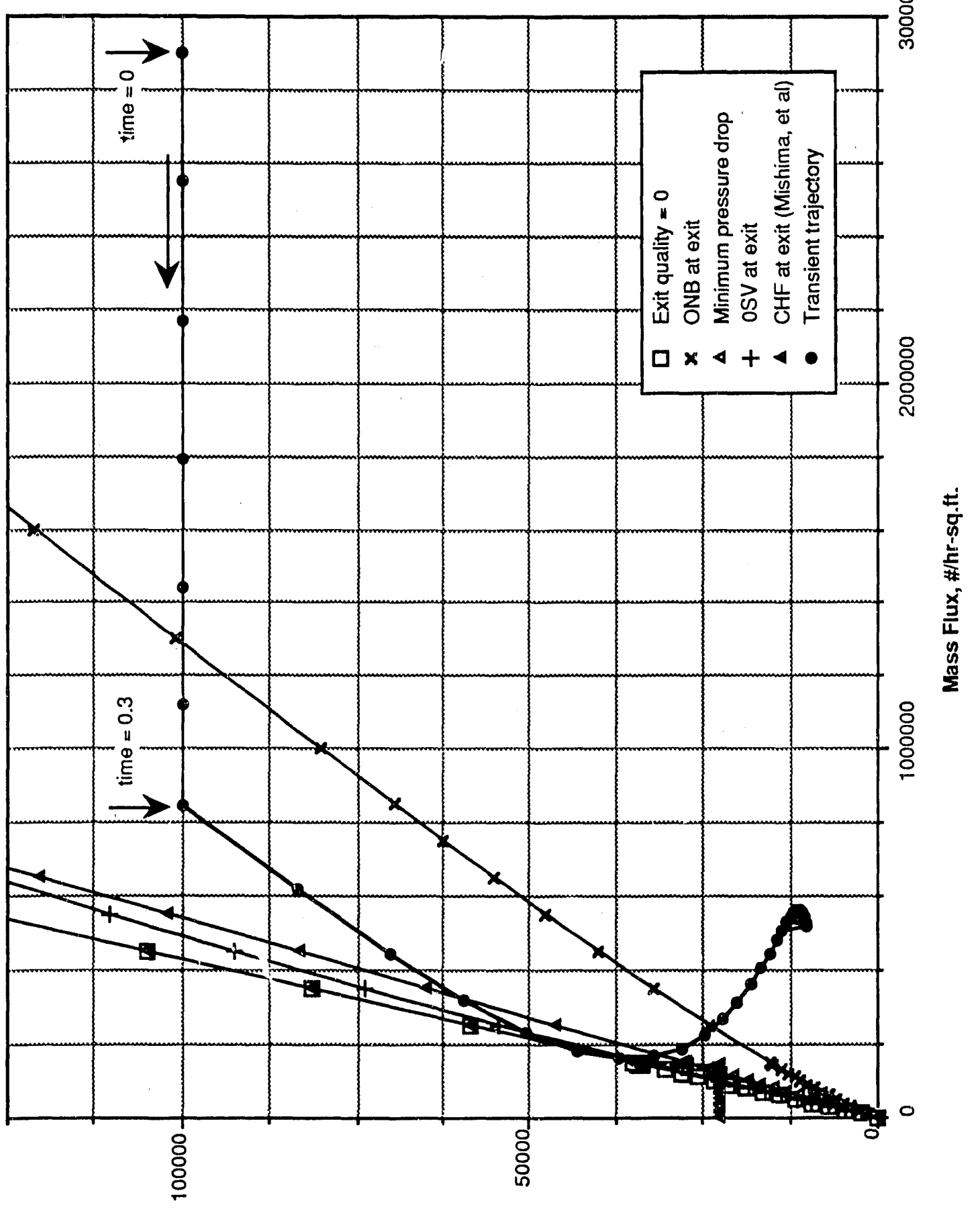

H'bs-sy/nig ' $x$ nIf $280 \mathrm{H}$

Figure 8, Compound Heat and Mass Flux Trajectory for an Inlet Temperature of $140^{\circ} \mathrm{F}$ 
TASK EXPERIMENTAL PLAN BOILING BEHAVIOR DURING FLOW INSTABILITY Category 1
Number: $91-063-1$

Revision: 0

9/6/91

Page 27 of 34

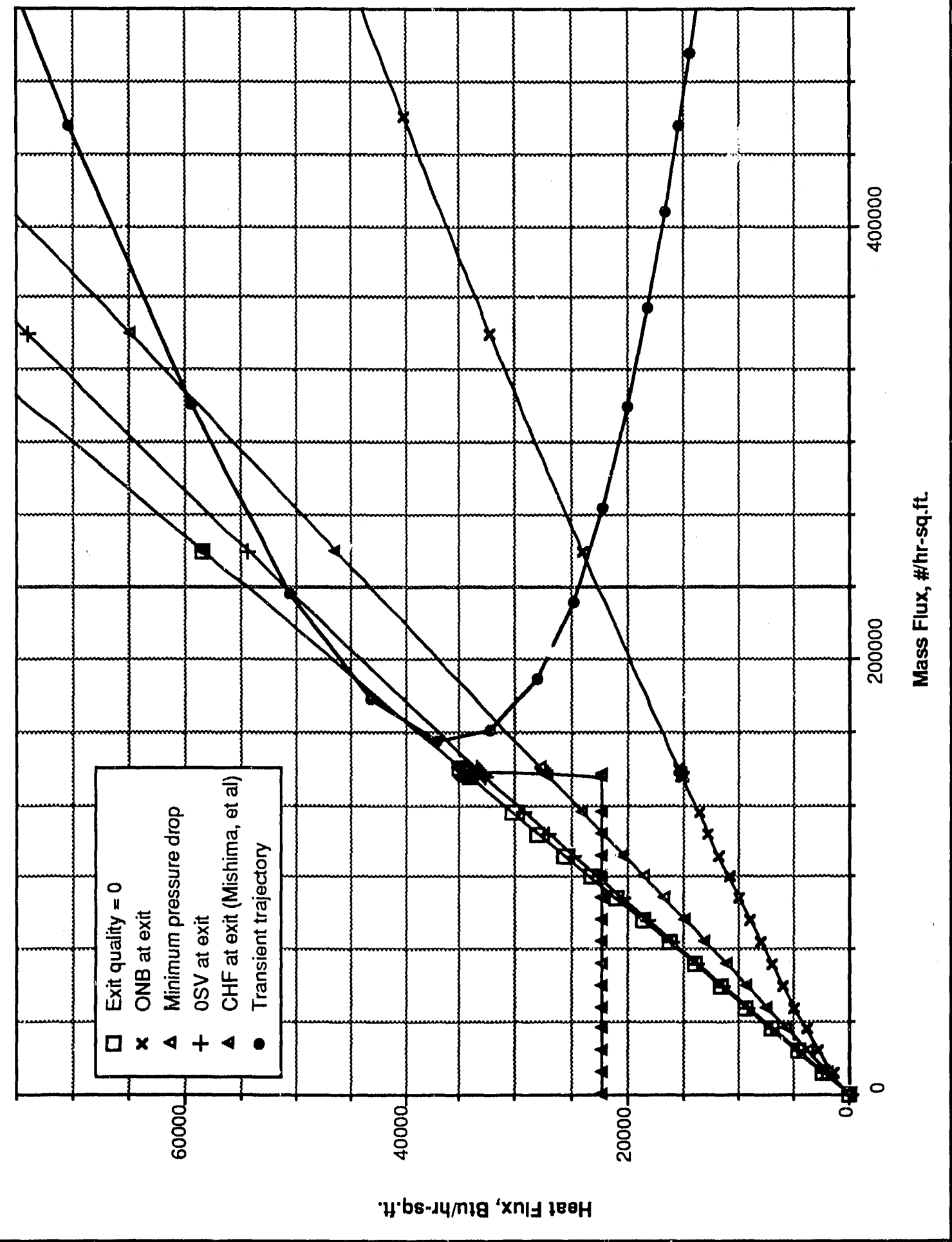

Figure 9, Compound Heat and Mass Flux Trajectory for an Inlet Teinperature of $140^{\circ} \mathrm{F}$ (detail of intercepts) 
TAEK EXPERIMENTAL PL. AN BOILING BEHAVIOR DURING Category 1
Number: 91-063-1

Revision: 0

9/6/91

Page 28 of 34

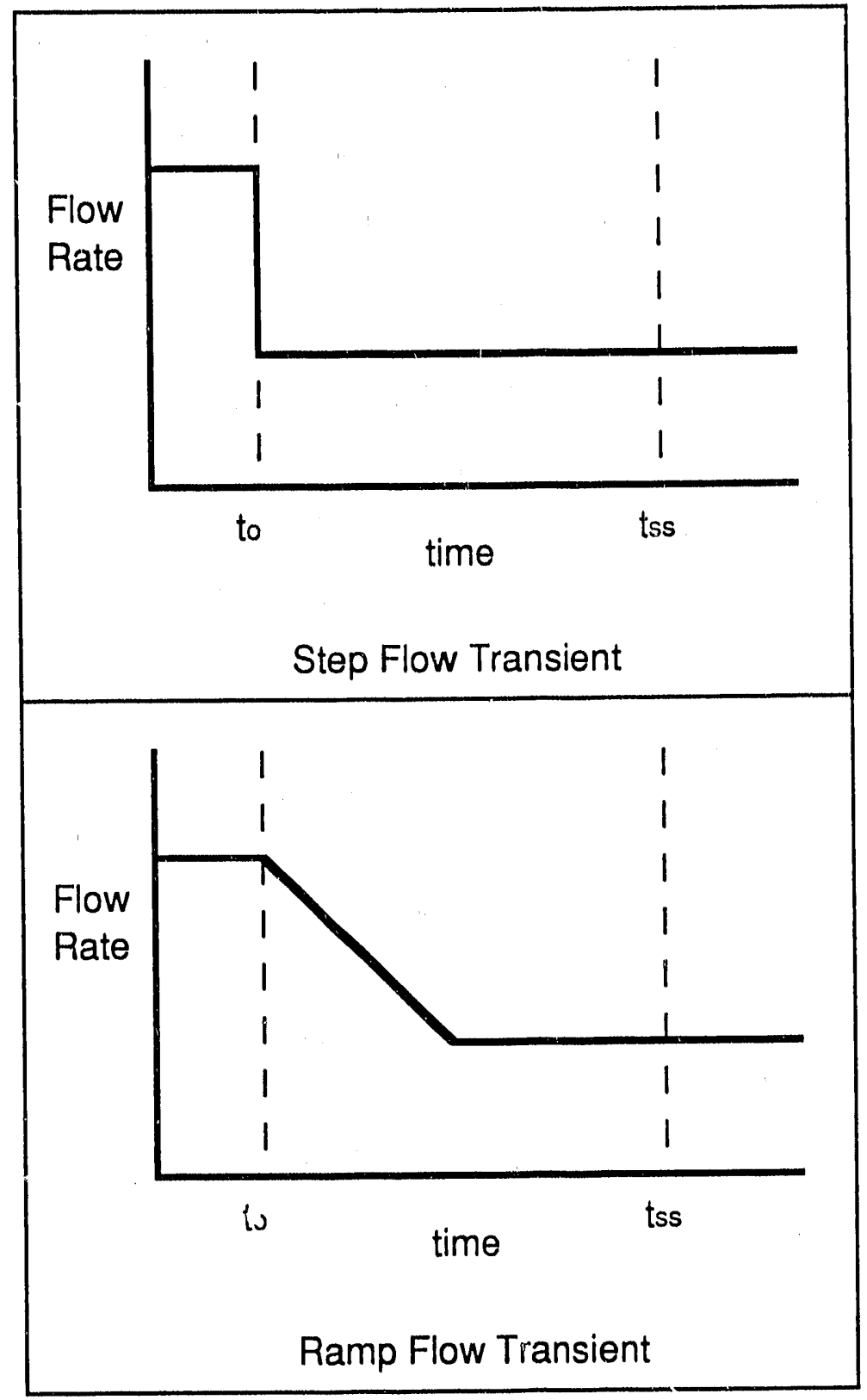

Figure 10, Imposed Flow Transients 


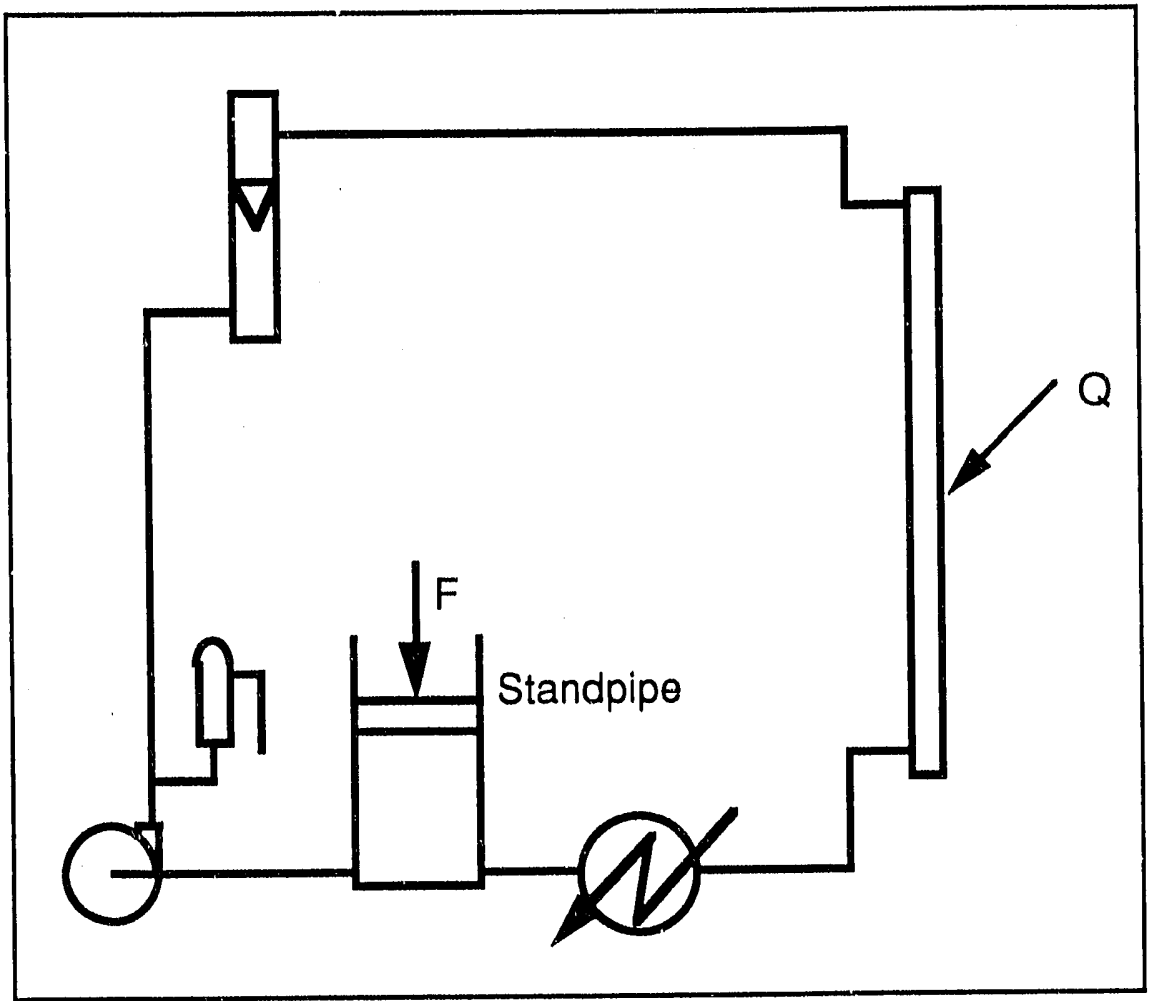

Figure 11, Rig Schematic 
Number: 91-063-1

Revision: 0

9/6/91

Pgge 30 of 34

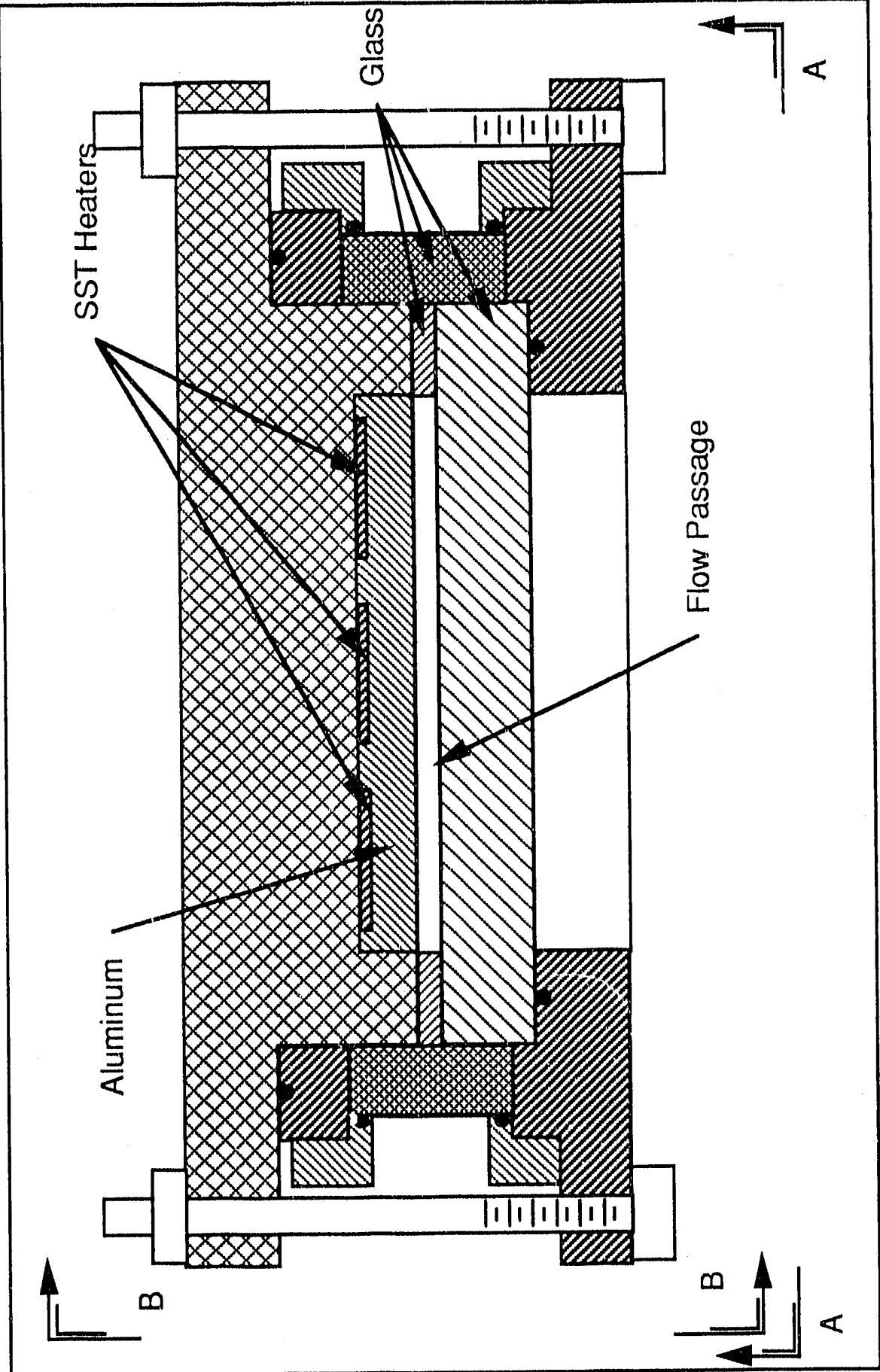

Figure 12, Flow Channel Section 


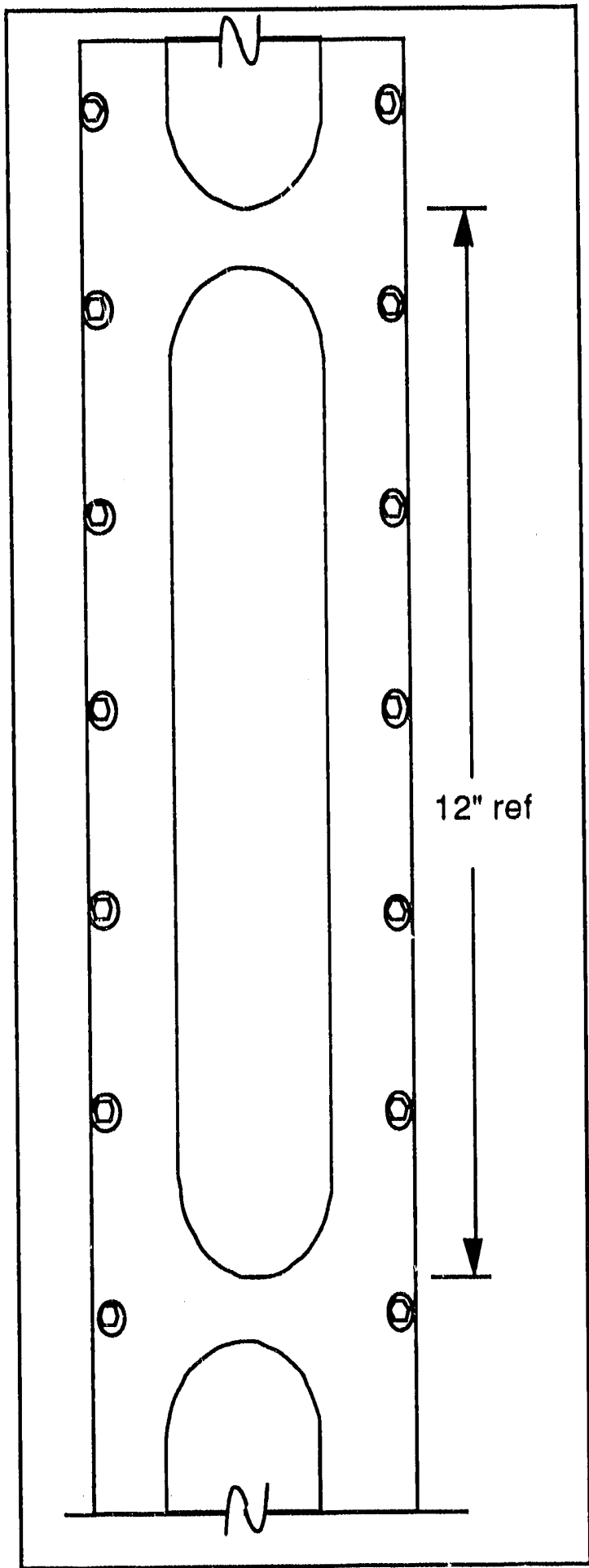

Figure 13, Section AA 


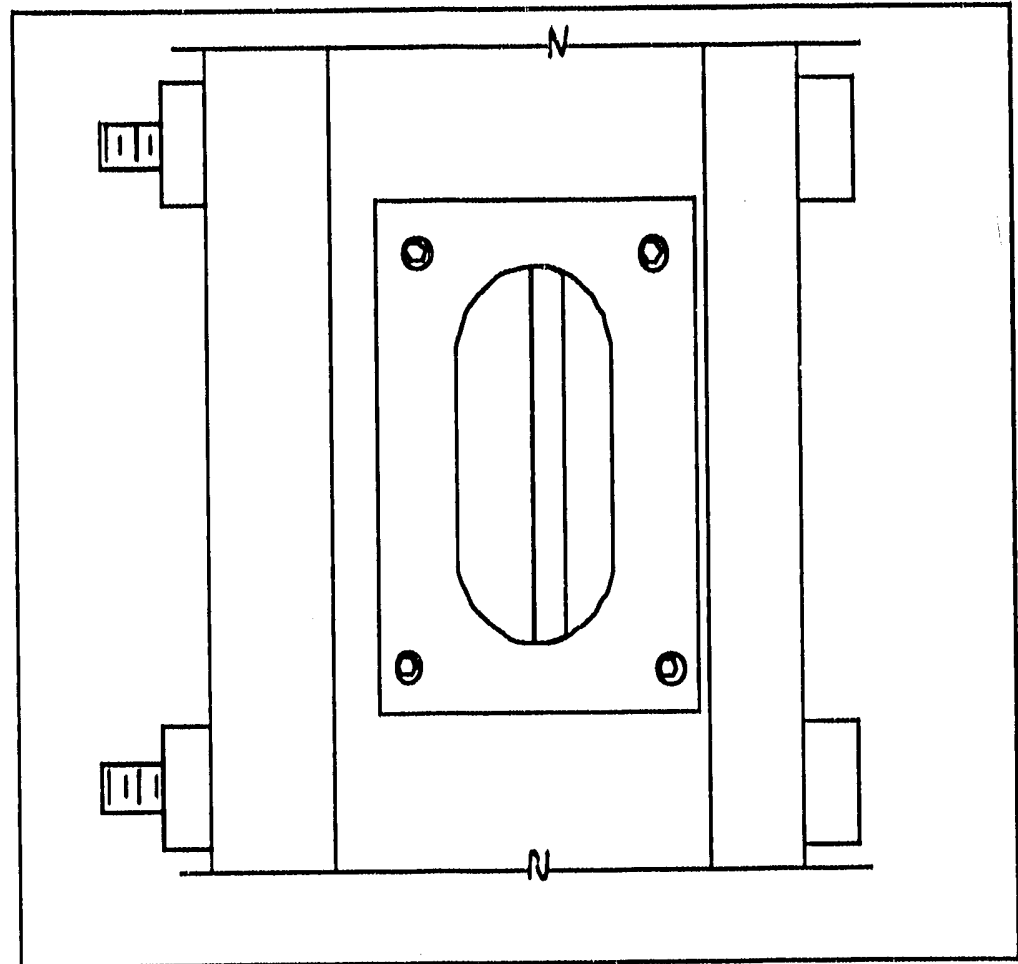

Figure 14, Section BB 
TASK EXPERIMENTAL PLAN

BOILING BEHAVIOR DURING FLOW INSTABILITY

Category 1
Number: 91-063-1

Revision: 0

$9 / 6 / 91$

Page 33 of 34

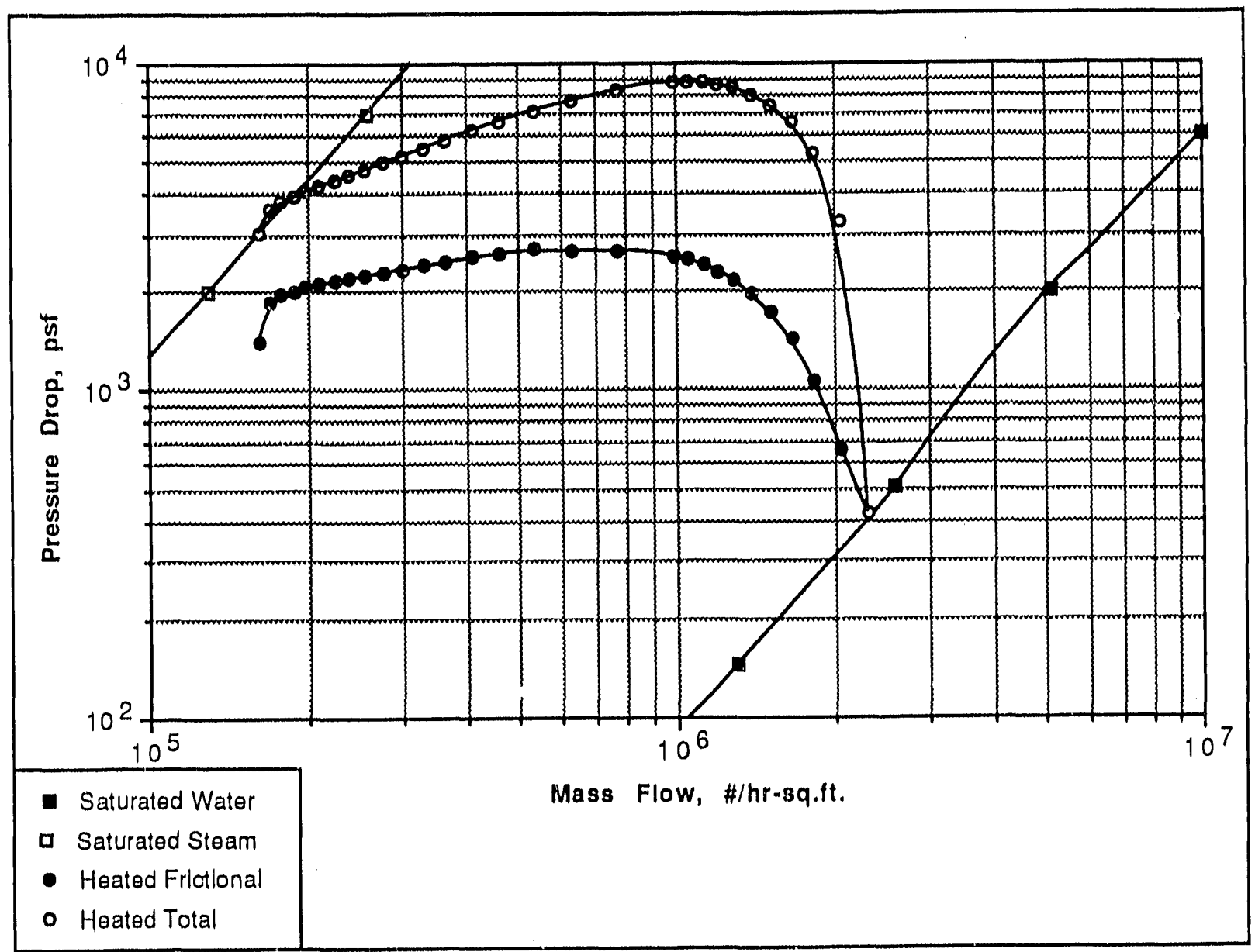

Figure 15, Typical Demand Curve for a Single Power Level 


\section{TABLE 1}

\section{Independent Test Varlables}

Flow Direction

Heat Flux

Heated Hydraullo Dlameter

Heated Length

Hydraulic Dlameter

Imposed Flow Transient

Initial Mass Flow Rate

Inlet Temperature

Mass Flow Rate Change

\begin{tabular}{|c|c|c|}
\hline \multicolumn{3}{|c|}{ TABLE 2 } \\
Proposed Testing Conditions \\
\hline Test Conditions & Primary & Secondary \\
\hline Channel width & $3^{\prime \prime}$ & $\mathrm{NA}$ \\
\hline Channel depth & $0.125^{\prime \prime}$ & 0.25 \\
\hline $\begin{array}{c}\text { Reynolds number } \\
\text { (nnlet steady state) }\end{array}$ & 10,000 & $1000,60,000$ \\
\hline Channel exit pressure & 15 psia & $\mathrm{NA}$ \\
\hline Heat flux & $\begin{array}{c}\text { Based on equation } \\
\text { to achieve } \mathrm{G}_{\text {Intial }}=1.2 \mathrm{G}_{\mathrm{O}}\end{array}$ & \\
\hline Inlet temperature & $60^{\circ} \mathrm{C}$ & $85^{\circ} \mathrm{C}$ \\
\hline Heated length & 4 feet & $\mathrm{NA}$ \\
\hline Flow direction & down & up \\
\hline Imposed Flow Transient & Step & $\begin{array}{c}\text { Ramp with } 1 / 2 \text { period for } \\
\text { solid water step transient }\end{array}$ \\
\hline
\end{tabular}



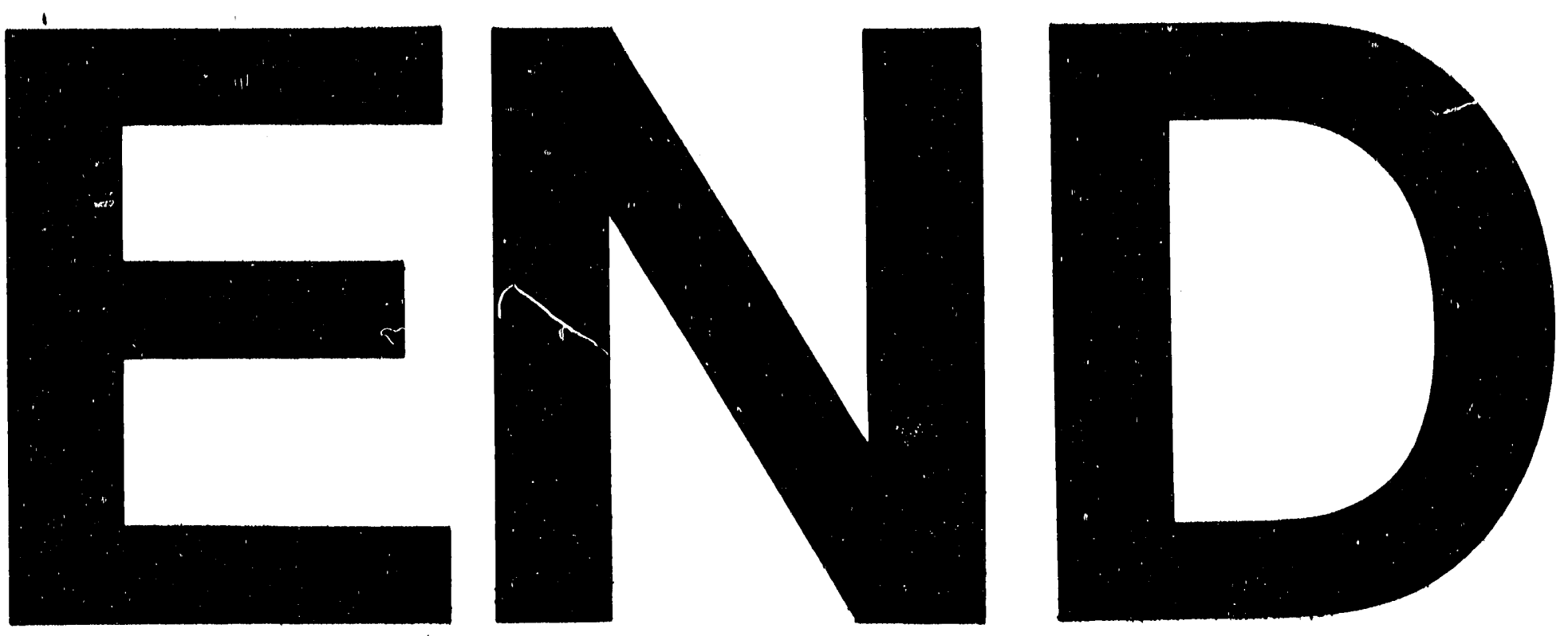

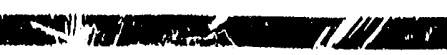

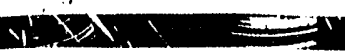

1 And
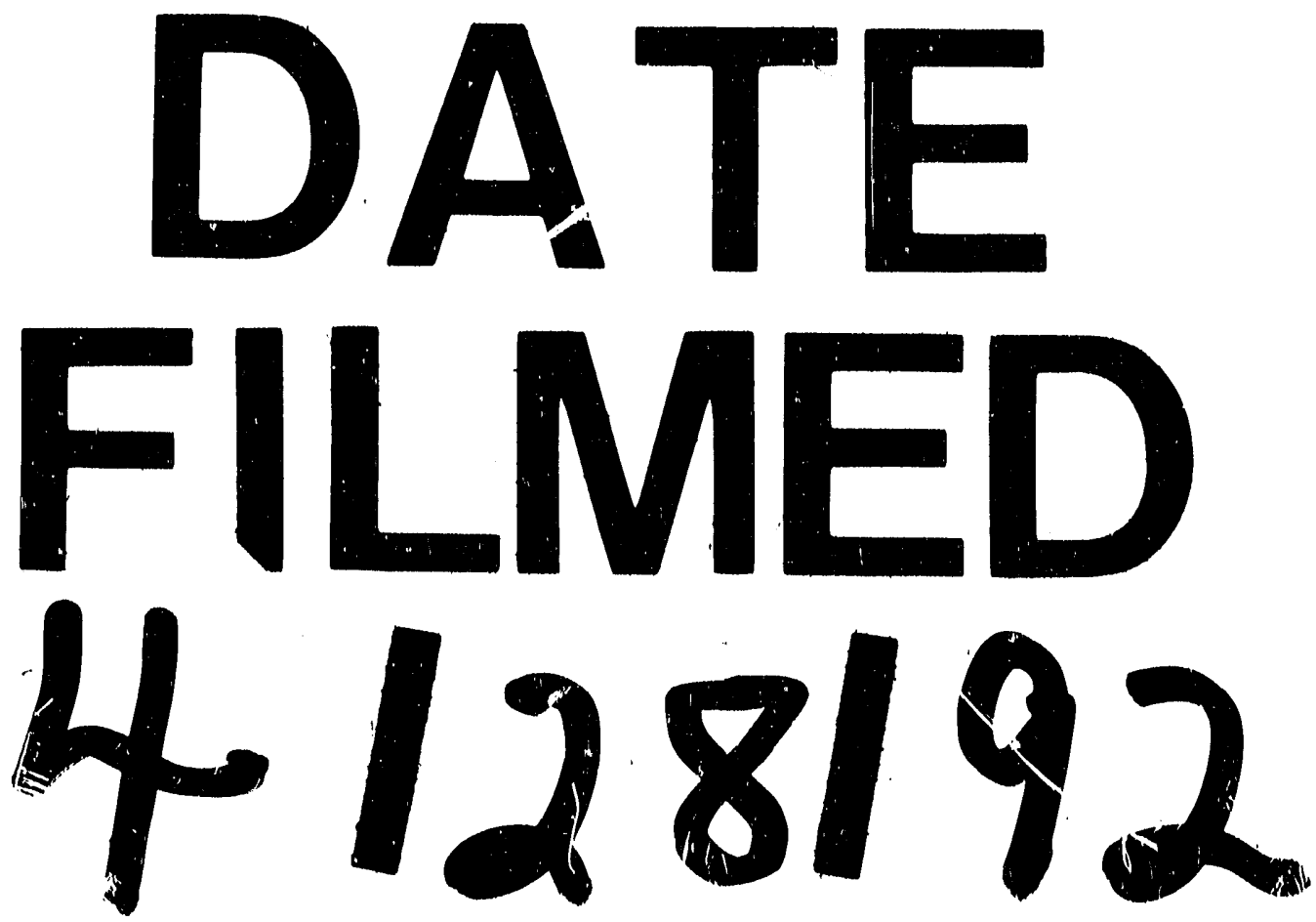
